\title{
Manipulation of Dietary Intake on Changes in Circulating Testosterone Concentrations
}

\author{
Amit Zamir, Tavor Ben-Zeev and Jay R. Hoffman *D \\ Department of Physical Therapy, Faculty of Health Sciences, Ariel University, 40700 Ariel, Israel; \\ amitza@ariel.ac.il (A.Z.); tavorbenzeev@gmail.com (T.B.-Z.) \\ * Correspondence: jayho@ariel.ac.il
}

Citation: Zamir, A.; Ben-Zeev, T.; Hoffman, J.R. Manipulation of Dietary Intake on Changes in Circulating Testosterone Concentrations. Nutrients 2021, 13, 3375. https://doi.org/10.3390/ nu13103375

Academic Editor: Margarida Castell Escuer

Received: 4 September 2021

Accepted: 23 September 2021

Published: 25 September 2021

Publisher's Note: MDPI stays neutral with regard to jurisdictional claims in published maps and institutional affiliations.

Copyright: (c) 2021 by the authors. Licensee MDPI, Basel, Switzerland. This article is an open access article distributed under the terms and conditions of the Creative Commons Attribution (CC BY) license (https:/ / creativecommons.org/licenses/by/ $4.0 /)$.

\begin{abstract}
Elevations in the circulating concentration of androgens are thought to have a positive effect on the anabolic processes leading to improved athletic performance. Anabolic-androgenic steroids have often been used by competitive athletes to augment this effect. Although there has been concerted effort on examining how manipulating training variables (e.g., intensity and volume of training) can influence the androgen response to exercise, there has been much less effort directed at understanding how changes in both macronutrient and micronutrient intake can impact the androgen response. Thus, the focus of this review is to examine the effect that manipulating energy and nutrient intake has on circulating concentrations of testosterone and what the potential mechanism is governing these changes.
\end{abstract}

Keywords: androgens; macronutrients; micronutrients; diet; aromatase activity

\section{Introduction}

Testosterone, together with its potent metabolite, dihydrotestosterone (DHT), are the principal androgens in the circulation of mature male mammals, including humans. They are important hormones for various biological processes and are vital for the development and maintenance of secondary male characteristics. They are also crucial for reproductive functions, body composition, and muscle and bone health [1,2].

As the primary anabolic steroid, testosterone promotes an increase in protein production as well as stimulating both anabolic and anti-catabolic functions in skeletal muscle and neuronal tissue leading to increased muscle strength, power, endurance, and hypertrophy in a dose-dependent manner [3]. Testosterone is also responsible for the mass, density, and strength of bone. As for its androgenic effects, testosterone mediates the development of male primary and secondary male characteristics such as sexual organ growth, deepening of the voice, and growth of facial and body hair [4].

Structurally, testosterone has a characteristic four ring C18 steroid structure and is synthesized from cholesterol through an enzymatic multistep process primarily within the Leydig cells ( $95 \%)$, which are located in the interstitium of the testes. The adrenal glands also produce small amounts $(\sim 5 \%)$ of androgens [5]. In women, testosterone is produced in much smaller amounts, primarily from the adrenal glands and the ovaries [2,6]. There are two metabolic pathways, the progesterone (delta-4) and dehydroepiandrosterone (DHEA) (delta-5) pathways [6]. Once synthesized, testosterone is secreted into the bloodstream and delivered to target tissues [7]. In the blood, most testosterone is transported bound to several proteins, mainly serum albumin and sex hormone-binding globulin (SHBG). A small amount is transported unbound, referred to as free testosterone (FT) [8]. FT is the active form of testosterone while protein-bound testosterone is inactive [9]. When testosterone reaches its target tissues it diffuses through the cells' fatty membrane, where it can interact with its receptor stimulating its biological effects or it can be reduced into DHT by the cytoplasmic enzyme $5 \alpha$-reductase, which is highly expressed in male reproductive organs, skin, and the brain [8]. 
Testosterone is synthesized under control of the hypothalamic-anterior pituitarygonadal axis. Gonadotropin-releasing hormone $(\mathrm{GnRH})$, released from the hypothalamus, stimulates the release of luteinizing hormone (LH) from the anterior pituitary gland into the circulation. LH then stimulates the Leydig cells within the testes to synthesize testosterone. Increasing circulating concentrations of testosterone will result in an inhibition of the release of the gonadotrophins ( $\mathrm{GnRH}$ and $\mathrm{LH}$ ) via a negative feedback loop mechanism. GnRH functions under the control of several hypothalamic neuropeptides [5].

The classical biological effects of androgens are primarily mediated by FT binding to the androgen receptor (AR). DHT binds to the same AR even more strongly than testosterone, so that its androgenic potency is about five times more potent than testosterone [10]. The AR complex undergoes a structural change that allows it to move into the cell nucleus and bind directly to specific nucleotide sequences of DNA, resulting in the transcription of certain genes. The AR complex itself serves as a transcription factor [7,11]. Testosterone can also be converted to estradiol (E2) by the aromatase enzyme and then activate certain estrogen receptors. Bone, adipose tissue, and the brain are tissues in humans where the primary effect of testosterone is via aromatization to E2 [4,12]. The enzyme aromatase is a member of the cytochrome P450 enzyme superfamily that catalyzes the conversion of androstenedione and testosterone to the aromatic estrogenic steroids estrone and estradiol, respectively [9]. These are the last key steps in the catalyzation of androgens into estrogens, hence inhibition of aromatase activity can elevate androgen concentrations. There are numerous natural substances that have been scientifically tested or suggested to inhibit aromatase activity, alongside pharmaceutical compounds whose non-medical use is considered illegal $[2,6]$.

Manipulation of testosterone concentrations without the use of anabolic steroids has been a highly investigated topic because of the known effect testosterone has on enhancing athletic performance [2,6]. While the use of androgens in competitive athletics is illegal, it has not stopped the search for "natural" ways to increase testosterone concentrations. In this review, we will examine the specific effect of various macronutrients and micronutrients on enhancing circulating testosterone concentrations at rest and during exercise. In addition, we will also discuss the role of low energy availability, a growing condition in the athletic population, and its effect on testosterone concentrations. While other reviews have previously discussed the effect of nutrition on testosterone status [13-16], most of these papers have examined the role of single nutrient (macro/micro) or food/food groups. To the best of our knowledge, this review is the first to focus on the nutrient influence on circulating testosterone concentrations. Its purpose is to provide an evidence-based assessment of how specific nutrients found in the diet or specific dietary manipulation can enhance the androgen response, with the assumption being that elevation in circulating androgens will enhance the anabolic response and potentially improve exercise performance.

\subsection{Natural Product Extracts and Aromatase Inhibition}

Extracts of many natural sources and nutrients, part of them used by traditional medicine, have been tested and found to possess aromatase inhibition activity. Figure 1 provides an overview of the effect that these various compounds have on aromatase activity. These natural sources include Brassaiopsis glomerulata from the Araliaceae plant family (i.e., ginseng). This species has several reported medicinal uses in south and southeast Asia, such as treatment of rheumatism and back pain, aiding in digestion and alleviating constipation, treating bone fractures and sprains, and other health issues [17]. Balunas and colleagues [18] reported strong aromatase inhibition of the hexane extract of Brassaiopsis glomerulata, coupled with the possibility of a favorable safety profile. Cycads have been used by numerous cultures for medicinal purposes such as the treatment of certain tumors, treating wounds, hemorrhoids, and more [19]. Kowalska and colleagues [19] reported five different species of cycad folia to have aromatase inhibition activity. These investigators reported that several other plant species also possess aromatase inhibition capabilities 
similar to the potent aromatase inhibitor, 10-propargylestr.4-ene-3,17-dione, including members of the Loranthaceae, Santalaceae and Zingiberaceae families, all flowering plants [20].

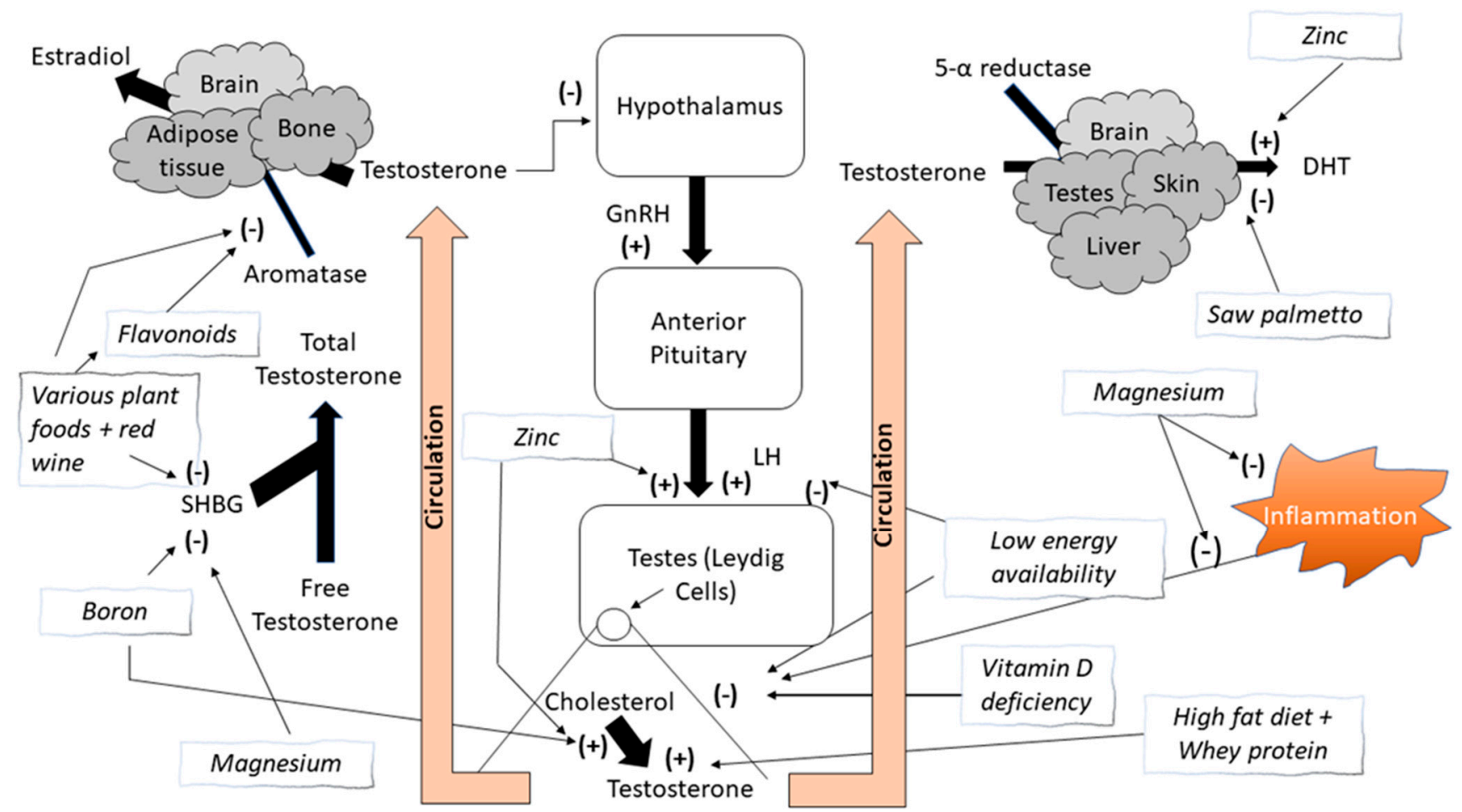

Figure 1. The effect of various food groups, macronutrients, and micronutrients on testosterone circulation and its proposed mechanisms. $(+)=$ Increases or stimulates; $(-)=$ Decreases or inhibits; DHT $=$ Dihydrotestosterone; $\mathrm{LH}=\mathrm{Luteinizing}$ hormone; $\mathrm{SHBG}=$ Sex hormone binding globulin.

Isodon excisus var. coreanus, a member of the Lamiaceae family, is one of the endemic plants in Korea, and has been used for the treatment of the anorexia, indigestion, stomachache, inflammation, and esophageal carcinoma [21]. Jeong and colleagues [22] reported four compounds isolated from this plant, including diethyl ether extract, inflexin, ursolic acid, and ursolic acid 3-O-acetate that have significant aromatase inhibitory activity. Lee and colleagues [23] reported that extracts from Euonymus alatus, a member of the Celastraceae family, also has potent aromatase inhibition.

The health benefits of red wine have been well-examined, and in recent decades studies have reported that red wine consumption has antioxidant, lipid regulating, and anti-inflammatory effects [24]. Interestingly, red wine has also been reported to result in aromatase inhibition. There have been five red wine varieties that have been reported to have aromatase inhibition activity, with the most active being cabernet sauvignon [25-27]. Consistent with the anti-aromatase benefits associated with red wine, Kijima and colleagues [28] reported that grape seed extract is a potent aromatase inhibitor and suppressor of aromatase expression. Shufelt and colleagues [29] reported that red wine consumption resulted in significantly higher FT concentrations and lower SHBG and E2 concentrations in women. This may have important implications regarding breast cancer risk. Interestingly, red wine was significantly more beneficial than white wine. Whether this same response is seen in men is not well understood.

Other food groups have also been reported to have anti-aromatase activity. White button mushrooms are known for their innate immune response enhancement [30,31] and their role in fat metabolism resulting in a decrease in cholesterol concentrations [31]. Grube and colleagues [32] reported that white button mushroom consumption can inhibit aromatase activity and breast cancer cell proliferation in women. However, there is limited evidence of this in men. Red clover flower extract, often used to improve hair and skin 
texture [33,34], has also been reported to inhibit 5- $\alpha$-reductase activity [35]. Interestingly, Almstrup and colleagues [35] reported that red clover flowers inhibit aromatase activity at low concentrations, but become estrogenic at higher concentrations, resulting in a U-shaped dose-response curve.

Balunas and colleagues [36] reported that an extract from a tropical fruit called mangosteen had strong inhibitory capabilities of the aromatase enzyme. Although this research team was primarily focused on the role that this fruit had on preventing or treating breast cancer, others have examined the ergogenic effect of this fruit. Konda and colleagues [37] examined the ergogenic effects of Garcina mangostana on both rodents and humans. Mice supplemented with Garcina mangostana experienced significantly greater swim times, swim distance, and grip strength than control mice. In addition, resistance-trained men were provided 42 days of the supplement $\left(800 \mathrm{mg} \cdot \mathrm{day}^{-1}\right)$ and experienced significant greater increases in maximal strength in the bench press and leg press exercise compared to a placebo-controlled group. In addition, the group consuming the supplement performed significantly more repetitions on the leg extension exercise and realized significantly greater increases in lean body mass and arm circumference than the placebo group. Significant improvements were reported in FT concentrations in the supplement group compared to the placebo group. To the best of our knowledge, this is the only study that has examined the anabolic effects of Garcina mangostana in humans. Further research on this extract appears warranted.

Sultan and colleagues [38] reported that an extract from saw palmetto (Serenoa repens), a type of a palm tree, decreases in vitro $5 \alpha$-reduction of androgens. Saw palmetto has been used to treat urinary tract infections and prostatic diseases [39]. Sudeep and colleagues [39] investigated 12 weeks of saw palmetto oil supplementation on androgen-deficient men and reported significant increases in both FT concentrations and quality of life in the supplemented men compared to placebo-treated men. Others have reported that two weeks of saw palmetto supplementation can significantly increase total testosterone and decrease DHT and E2 concentrations using both low $\left(800 \mathrm{mg} \cdot \mathrm{day}^{-1}\right)$ and high $\left(2000 \mathrm{mg} \cdot \mathrm{day}^{-1}\right)$ doses [40]. Although the efficacy of saw palmetto has been demonstrated in androgendeficient men, there is limited data on younger, eugonadal men.

There are numerous other plant extracts from collards, tomato leaves, tea, coffee, cocoa, kale, potato leaves that have been reported to have high aromatase inhibition activity [41]. However, most of the research has been conducted on clinically relevant populations, and not on young, athletic men to enhance androgen response. Regardless, the mechanism responsible for much of the aromatase inhibition attributed to these products is attributed to the flavonoid content of these nutrients.

\subsection{Flavonoids}

Several compounds belonging to the class of flavonoids have been suggested to act as aromatase inhibitors [38]. Flavonoids are a group of natural substances with variable phenolic structures. They belong to a class of plant secondary metabolites and are widely found in fruits, vegetables, and certain beverages [42]. These natural products are well known for their beneficial effects on health due to their antioxidative, anti-inflammatory, anti-mutagenic, and anti-carcinogenic properties coupled with their capacity to modulate key cellular enzyme functions [42] including aromatase inhibition [43]. Most of the biological activities of flavonoids are attributed to a catechol group in their B-ring, 2,3-double bond conjugated with the 4-oxo function and a 3- (and 5-) hydroxy group that scavenge superoxide anions, hydroxyl, peroxyl, alkoxyl and the nitric oxide radicals, and by that eliminate lipid peroxidation [44].

There are numerous types of flavonoids found in various foods, providing potential anti-aromatase activity in many of the nutrients common in one's diet. Apigenin is a flavonoid found in many fruits and vegetables, but commonly found in parsley, celery, celeriac, and chamomile tea [45]. Flavonoids are also found in beer. Xanthohumol-rich stout beer contains a high concentration of prenylflavonoids and is noted for its ability 
to inhibit aromatase activity [46]. Other flavonoids such as catechins exist in high concentrations in cocoa [47], prune juice [48], and Açaí oil [49]. Neves and colleagues [50] identified several flavonoids as equal or better aromatase inhibitors in comparison to the anti-aromatase drug aminoglutethimide, including flavones, flavanones, resveratrol, and oleuropein. Flavones and flavanones are found in many fruits and green tea, resveratrol is one of the main components of red wine, and oleuropein is found in olive oil. Several studies have reported high anti-aromatase activity in chrysin, a flavonoid present in high concentrations in honey and propolis $[48,51,52]$. However, others reported no change in testosterone concentrations in men consuming honey and propolis for 21 days [53]. Consuming foods or dietary supplements containing nutrients with aromatase inhibitors may provide an ergogenic effect by inhibiting the conversion of testosterone to estradiol, indirectly increasing testosterone concentrations. Unfortunately, most studies that have focused on the effect of various foods on aromatase inhibition have been primarily interested in the potential clinical use for treatment or prevention of various diseases such as breast cancer, and not on the ergogenic potential that they may have for competitive athletes. Additional research is needed to investigate the potential ergogenic effect aromatase inhibitors have on testosterone concentrations in athletic populations.

\subsection{Other Nutrients}

There have been other naturally occurring nutrients that have been suggested to have a potential anabolic effect by increasing testosterone concentrations. A multi-ingredient supplement consisting of indole-3-carbinol (an extract from cruciferous vegetables), chrysin, saw palmetto, and Tribulus terrestris, a plant of the Caltrop family, consumed in combination with the pro-hormones androstenedione and dehydroepiandrosterone increased FT concentrations to a greater extent in middle-aged men compared the pro-hormones only [54]. Others have examined the capability of the element boron on its testosterone-boosting capability [55-57]. Evidence does indicate significant elevations in testosterone concentrations in post-menopausal women [55] and in healthy men [56] following boron supplementation, but other examining weightlifters showed no difference between athletes supplementing with boron compared to placebo [57]. The mechanism suggested that enhancing testosterone concentrations from boron intake is related to boron's role in the hydroxylation step during testosterone formation [58], and by its ability to decrease SHBG [59]. A decrease in SHBG levels would result in an increase in FT concentrations. Various foods such as fruits, tubers, wine, cider, beer, coffee, milk, dried and cooked beans, potatoes, and legumes contain the largest amounts of boron [60]. Additional research appears warranted regarding boron's efficacy in increasing testosterone concentrations.

Phosphatidylserine (PS) has also been proposed to enhance the anabolic response to exercise. However, there is only limited human evidence supporting this hypothesis. PS is a phospholipid found in the cell membrane of a variety of tissues, including the brain, lungs, heart, liver, and skeletal muscle. The best dietary sources of PS are organ meats such as brain, liver, heart, and kidney. Fatty fish, meats, and white beans can also provide PS in smaller amounts. In a study on healthy, young men, Starks and colleagues [61] reported that PS supplementation significantly increased the testosterone to cortisol ratio during a bout of moderate intensity exercise on a cycle ergometer. Despite these positive results, there does not appear to be any additional research supporting the role of PS on changes in testosterone concentrations. However, other investigators examining another phospholipid (i.e., phosphatidic acid) reported an increase in both strength and muscle thickness in young, healthy men [62]. However, the mechanism that was suggested was related to the role that phosphatidic acid may have on stimulating the mTor protein signaling pathway and not to an augmented androgen response. However, the latter was not measured.

There appears to be an abundance of testosterone boosters that are marketed to the consumer. Balasubramanian and colleagues [63] recently examined the efficacy of the five top-ranked products and reported that the number of human studies conducted provided no definitive evidence for the efficacy of these products. Similarly, Clemesha 
and colleagues [64] reported that only $\sim 25 \%$ of the 50 products they tested claiming to be testosterone boosters had scientific data to support their claims. This is an area of study that has much appeal to competitive strength/power athletes, but the evidence to support the use of these nutrients is often lacking.

\section{Macronutrient Effects on Changes in Testosterone Concentrations}

\subsection{Low Energy Availability and Calorie Intake}

Competitive athletes focusing on enhancing their athletic performance often strive to improve their body composition by increasing lean body mass and decreasing fat mass [65-67]. In the absence of appropriate guidance (e.g., consultation from a sport nutritionist), many athletes alter their dietary intake potentially creating an energy deficit, which is often associated with low energy availability [68]. Energy availability is defined as the difference between energy intake and energy expenditure, relative to an individual's fat-free mass (FFM) [69]. Low energy availability may reduce the body's energy reserves, limiting its ability to support normal physiological function needed to maintain optimal health [68]. For example, an athlete training at a high intensity or prolonged duration, while attempting to lose fat mass by reducing caloric intake, may cause a low energy availability. It is recommended that athletes have an energy availability of $>45 \mathrm{kcal} \cdot \mathrm{kg}$ FFM $\cdot \mathrm{day}^{-1}$. Low energy availability is defined as $<30 \mathrm{kcal} \cdot \mathrm{kg}$ FFM·day ${ }^{-1}$ [69-71]. The impact of low energy availability on various physiological systems in the body is not the primary scope of this paper, instead, the focus is directed on the effect of low energy availability on circulating testosterone concentration and testosterone biosynthesis.

Several studies have demonstrated that a low energy availability can decrease LH concentrations, subsequently affecting testosterone synthesis. Initial investigations reported that a low energy availability (i.e., $13 \mathrm{kcal} \cdot \mathrm{kg}$ FFM·day ${ }^{-1}$ ) significantly altered LH pulse frequency and amplitude [72]. Subsequent research, examining an even lower energy availability (i.e., $10 \mathrm{kcal} \cdot \mathrm{kg}$ FFM·day ${ }^{-1}$ ) also reported significant decreases in LH production and LH pulse frequency [73]. Another investigation, comparing study participants experiencing a low energy availability of $<30 \mathrm{kcal} \cdot \mathrm{kg}$ FFM $\cdot$ day $^{-1}$ to study participants with an energy availability of $45 \mathrm{kcal} \cdot \mathrm{kg}$ FFM $\cdot \mathrm{day}^{-1}$ reported a significant reduction in LH production and pulse frequency in the lower energy available group [74]. These studies clearly indicate the negative effect that low energy availability has on the hypothalamic-pituitary-gonadal axis.

Large energy deficits appear to negatively affect testosterone concentrations. $\mathrm{Hu}$ and colleagues [75] observed a significant decrease in testosterone concentrations when dietary macronutrient intake was reduced. Others have reported that a $40 \%$ reduction in total caloric intake was associated with significant decreases in circulating testosterone concentrations, despite a high percentage of the caloric intake being from protein sources [76]. Situations of low energy availability are reported in both endurance and strength/power athletes and are especially relevant in sports where competition is based upon weight class [77]. One investigation examining the effects of energy restriction and training volume on circulating testosterone concentrations reported a significant reduction in testosterone concentrations among physique athletes who increased their training volume, while being energy-restricted compared to physique athletes who maintained their regular diet and training volume [78] (described in Table 1). Additional research reported significant decreases in testosterone concentrations in long-distance runners who were categorized as "low energy available" (<30 kcal·kg FFM·day $\left.{ }^{-1}\right)$ compared to runners categorized as "moderate energy available" (30-45 kcal·kg FFM·day $\left.{ }^{-1}\right)$ [79]. Others have reported significant elevations in cortisol, decreases in testosterone, and a lower testosterone/cortisol ratio $24-\mathrm{h}$ following an intense exercise session resulting in an energy deficit exceeding $400 \mathrm{kcal}$ in male athletes [80]. These investigations have indicated that low energy availability has a deleterious effect on various physiological systems in the body, specifically the endocrine system. 
Table 1. Effect of low energy availability and energy deficits on circulating testosterone concentrations.

\begin{tabular}{|c|c|c|c|c|}
\hline Source & Participants & Duration & Intervention & Key Findings \\
\hline [78] & $\begin{array}{l}n=14 \text { men } \\
\text { Elite bodybuilders }\end{array}$ & 11 weeks & $\begin{array}{l}\text { Energy-restricted group }(n=7) \text { : decrease calories and increase energy } \\
\text { expenditure through exercise } \\
\text { Control group }(n=7) \text { : energy intake and training volume were } \\
\text { maintained. }\end{array}$ & $\begin{array}{l}\text { - } \quad \text { Significant decrease in TT in the } \\
\text { energy-restricted group compared to } \\
\text { the control group } \\
\text { - } \quad \text { ES energy-restricted group }=0.49 \\
\text { - } \quad \text { ES control group }=0.07 .\end{array}$ \\
\hline [76] & $\begin{array}{l}n=34 \text { Healthy adults } \\
\text { (men and women) }\end{array}$ & 31 days & $\begin{array}{ll}\text { - } & 40 \% \text { energy deficit for all protein intake groups } \\
\text { - } & \text { Group } 1(n=11 ; 10 \text { males, } 1 \text { female })-0.8 \mathrm{~g} \cdot \mathrm{kg}^{-1} \cdot \text { day }^{-1} \\
\text { - } & \text { Group } 2(n=12 ; 10 \text { males, } 2 \text { females })-1.6 \mathrm{~g} \cdot \mathrm{kg}^{-1} \cdot \text { day }^{-1} \\
& \text { Group } 3(n=10 ; 8 \text { males, } 2 \text { females })-2.4 \mathrm{~g} \cdot \mathrm{kg}^{-1} \cdot \text { day }^{-1}\end{array}$ & 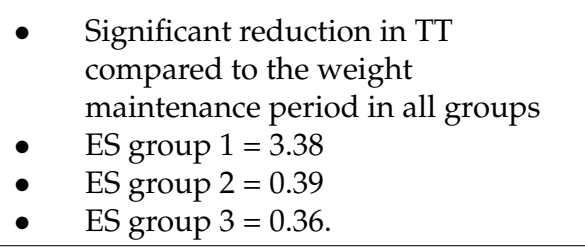 \\
\hline [79] & $\begin{array}{l}n=24 \text { males } \\
\text { Elite distance runners }\end{array}$ & 7 days & $\begin{array}{l}\text { - } \quad \text { Low energy available group }(n=6):\left(<30 \mathrm{kcal} \cdot \mathrm{kg} \text { FFM } \cdot \mathrm{day}^{-1}\right) \\
\text { - }\end{array}$ & $\begin{array}{l}\text { - Significant reduction in TT in the } \\
\text { low energy available group } \\
\text { compared to the moderate energy } \\
\text { available group ES }=1.3 \text {. }\end{array}$ \\
\hline
\end{tabular}

FFM = Fat free mass; TT = Total testosterone concentrations; ES = effect size. Effect size was estimated as (mean 2 - mean 1)/pooled standard deviation 


\subsection{High-Fat Diets and Dietary Fats}

For the hormonal system to function optimally, fat becomes an important macronutrient as it's the backbone for steroid hormone production [81]. The minimum recommendation for dietary fat consumption should be not below $25 \%$ for both the general and athletic populations [82-84]. Cholesterol, a dietary fat component, is one of the building blocks for testosterone production [81]. Considering that high-fat diets (HFD) increase cholesterol levels, increases in dietary fat consumption have been suggested to potentially result in an increase in testosterone production [85]. Several studies have examined the effect of HFD on circulating testosterone concentrations [85-87]. One study examined the effect of ketogenic (KD) and non-ketogenic (NKD) diets on strength, body composition, and hormonal profile in resistance-trained men [84]. Both study groups consumed a diet high in fat ( $75 \%$ vs. $65 \%$ for the KD and NKD, respectively). The primary difference between the diets was that the KD group ingested a very low amount of dietary carbohydrates $(5 \%)$ compared to the NKD $(15 \%)$. Both groups participated in a 12-week resistance training program. Results indicated that both groups experienced a significant increase from baseline in both total testosterone (TT) and FT concentrations during all four assessment times (weeks 2, 4, 6, and 8) of the study. In addition, TT and FT concentrations at weeks 4, 6, 8 were significantly elevated compared to week 2 . Although the investigative team did not employ a control group consuming a low-fat diet (LFD), the results do suggest that a HFD rich in cholesterol increased TT and FT in resistance-trained men regardless of the state of ketosis. A similar study [86] investigated the differences between KD and Western diets (WD) on body composition, strength, power, and hormonal profiles in resistance-trained men. In this study, a large difference in carbohydrate and fat consumption was noted between the two groups. The macronutrient profile for the WD group was $20 \%, 55 \%$, and $25 \%$ for protein, carbohydrate, and fat, respectively, while for the KD group it was $20 \%, 5 \%$, and $75 \%$, respectively. Both groups participated in a 10-week resistance training program. Although both groups had similar increases in muscle thickness, lean body mass, and strength measures (1RM squat and bench press), only the KD group experienced a significant increase in TT concentrations. It has been suggested that increases in testosterone concentrations resulting from a KD are related to the high dietary intake of cholesterol [88]. Another study examining the effect of dietary nutrients on testosterone concentrations in resistance-trained individuals reported a significant correlation $(\mathrm{r}=0.72)$ between resting testosterone concentrations and dietary fat consumption [83]. An investigation in women reported that a diet that included $40 \%$ of its calories from dietary fat was superior for increasing testosterone and estrogen concentrations compared to a diet whose total fat intake was $20 \%$ of its total caloric intake [89] (described in Table 2). A recent systematic review investigated the effect of a LFD on testosterone concentrations in men [85]. The LFD had a small-to-moderate effect on decreasing total testosterone concentrations compared to the HFD. Although evidence points to a positive effect of dietary fat on circulating testosterone concentrations, it should not be dismissed that fat is not the optimal fuel source for athletes participating in strength/power sports [83,90-92]. As such, sport nutritionists may hesitate in recommending high-fat diets.

\subsection{Dietary Protein and Protein Supplements}

Dietary protein intake has an important role in athletic performance. Skeletal muscle, the site for force production, is predominantly comprised of protein [93]. Dietary protein supports the replenishment of skeletal muscle protein as it is degraded or damaged by intense exercise $[94,95]$. Exercise and inadequate protein intake can result in a catabolic response of muscle. That is, if protein intake is not adjusted to meet the protein needs of the body, the ability to maintain or increase muscle mass and muscle performance becomes challenging. To maintain appropriate muscle protein balance, in which muscle protein synthesis equals or exceeds muscle protein breakdown, dietary protein intake for athletes is recommended to be between $1.6-2.2 \mathrm{~g} \cdot \mathrm{kg}^{-1} \cdot \mathrm{day}^{-1}$ [96-98]. Although dietary protein has an important role in skeletal muscle size and strength adaptations, the influence of dietary 
protein intake on testosterone concentrations does not appear to have a major role, and the general recommendations of $1.6-2.2 \mathrm{~g} \cdot \mathrm{kg}^{-1} \cdot \mathrm{day}^{-1}$ appear to be sufficient to optimize testosterone concentrations [94].

One type of protein that has received considerable attention regarding its effect on circulating testosterone concentrations is soy protein. Although soy protein consumption has been demonstrated to have significant benefits on strength performance following 12 weeks of resistance training [99], its role in androgen biology has made it a topic of interest. This interest is related to the understanding that soybeans contain biologically relevant amounts of isoflavones [100]. Isoflavones are also referred to as phytoestrogens and are compounds that bind to estrogen receptors, causing a cascade of events that exert estrogen-like effects [101,102]. The popularity of soy protein use among vegan athletes has resulted in a focus on its effect on sport performance and changes in testosterone concentrations. Studies on male rodents have resulted in conflicting results. Some investigations have indicated that rodents fed soy protein exhibited lower serum testosterone concentrations $[103,104]$, while others reported no negative effects on circulating testosterone $[105,106]$. A meta-analysis examining the effect of isoflavones and soy protein intake on testosterone concentrations and SHBG in men concluded that there was no negative effect of soy protein intake on TT, FT, or SHBG [107]. However, subsequent research continues to still raise the issue that soy protein consumption can result in reductions in resting testosterone concentrations and response to exercise. Kraemer and colleagues [108] examined the effect of soy protein supplementation on the testosterone and estradiol response in healthy, resistance-trained men. Using a cross-over design, participants were randomized into three groups: whey protein supplement (WPS), soy protein supplement (SPS), and maltodextrin (placebo, PLA). Participants were provided each treatment for 14 days. Following the supplementation period, participants performed an acute resistance exercise session consisting of 6 sets of 10 repetitions in the squat exercise at $80 \%$ of the participant's one repetition maximum. Testosterone and estradiol concentrations were examined at various time points during and following the acute exercise session. Although testosterone concentrations were significantly elevated from baseline during and up to 5-min post-exercise, only the WPS and PLA trials resulted in significant increases in testosterone concentrations at the 15- and 30-min post-exercise measures. Additionally, testosterone concentrations were significantly lower during SPS compared to both WPS and PLA during the post-exercise period. No significant differences were noted in estradiol concentration between the three groups at any of the time points. Subsequent research, using the same three groups, albeit for 12 weeks and combined with resistance exercise, also reported no significant pre- or post-training changes in serum estradiol concentrations in any of the study groups [109]. Although no significant differences were noted in TT concentrations in both the SPS and PLA groups, an increase in serum TT was observed in the WPS group. In addition, muscle androgen-responsive mRNA was increased in all groups as a result of the training stimulus (significant main effects for time), but no significant differences were observed between the three groups. The results from these studies do not provide any conclusive evidence regarding soy protein having a negative effect on testosterone production. However, they are consistent in demonstrating that whey protein supplementation may be the superior protein supplement for enhancing the testosterone response to training. It is also important to note that protein supplementation regardless of its source (soy or whey), when combined with resistance training can result in a significant increase in lean body mass [110]. 
Table 2. Effect of fat and protein intake on changes in circulating testosterone concentrations.

\begin{tabular}{|c|c|c|c|c|}
\hline Source & Participants & Duration & Intervention & Key Findings \\
\hline [89] & $\begin{array}{l}n=48 \\
\text { Premenopausal healthy women }\end{array}$ & 14 weeks & $\begin{array}{ll}- & \text { HFD group }(n=24): 40 \% \text { fat } \\
- & \text { LFD group }(n=24): 20 \% \text { fat }\end{array}$ & $\begin{array}{ll}\text { - } & \text { Significant decrease in TT concentrations } \\
\text { - } & \text { Significant decrease in estrone concentrations } \\
\text { - } & \text { Significant decrease in SHBG concentrations } \\
\end{array}$ \\
\hline [108] & $\begin{array}{l}n=10 \\
\text { Healthy resistance-trained men } \\
\text { (crossover design) }\end{array}$ & 10 weeks & $\begin{array}{ll}- & \text { WPI }(n=10) \\
- & \text { SPI }(n=10) \\
\text { - } & \text { Placebo }(n=10)\end{array}$ & $\begin{array}{l}\text { - Significant increase in the TT response to resistance } \\
\text { exercise test for all groups. } \\
\text { Significantly lower TT concentrations in SPI group } \\
\text { post-resistance exercise compared to both WPI and } \\
\text { placebo groups. }\end{array}$ \\
\hline [109] & $\begin{array}{l}n=47 \\
\text { Healthy college-aged men } \\
\text { performing a resistance training } \\
\text { program }\end{array}$ & 12 weeks & $\begin{array}{ll}- & \text { WPI }(n=17) \\
- & \text { SPI }(n=15) \\
- & \text { Placebo }(n=15)\end{array}$ & $\begin{array}{l}\text { - No significant differences in TT concentrations between } \\
\text { SPI and placebo groups } \\
\text { - } \quad \text { ES SPI }=0.04 \\
\text { - } \quad \text { SS PLA }=0.15 . \\
\text { - } \\
\text { - } \quad \text { Signifificant increase in serum to baseline in the WPI group }(\mathrm{ES}=0.63) . \\
\text { androgen-responsive mRNA, but no significant } \\
\text { differences noted between groups. } \\
\text { - } \quad \text { ES PLA }=0.05 \\
\text { - } \quad \text { ES SPI }=0.28 \\
\text { ES WPI }=0.59 .\end{array}$ \\
\hline [86] & $\begin{array}{l}n=25 \\
\text { Resistance-trained men }\end{array}$ & 11 weeks & $\begin{array}{ll}- & \text { Ketogenic diet } \\
- & (n=13) \\
- & \text { Western diet } \\
- & (n=12) \\
\end{array}$ & $\begin{array}{l}\text { - Significant increase in TT concentrations in the ketogenic } \\
\text { diet compared to western diet group } \\
\text { ES }=0.65 \text {. }\end{array}$ \\
\hline [111] & $\begin{array}{l}n=18 \text { Experienced, } \\
\text { resistance-trained, middle-aged men }\end{array}$ & 8 weeks & $\begin{array}{ll}- & \text { Ketogenic diet } \\
- & (n=9) \\
- & \text { Non-ketogenic diet }(n=9)\end{array}$ & $\begin{array}{l}\text { - Significant increase in both TT and FT in both the } \\
\text { ketogenic and non-ketogenic groups. } \\
\text { - } \quad \mathrm{ES}, \mathrm{KD} \text { for TT }=1.98, \mathrm{TF}=1.66 \\
\text { - } \mathrm{ES}, \mathrm{NKD} \text { for } \mathrm{TT}=2.27, \mathrm{TF}=2.31\end{array}$ \\
\hline
\end{tabular}

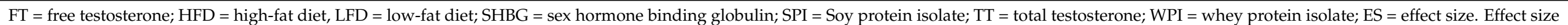
was estimated as- (mean 2 - mean 1)/pooled standard deviation. 


\section{Micronutrient Effects on Testosterone Concentrations}

\subsection{Vitamin $D$}

Vitamin D is a micronutrient that also acts as a prohormone [112]. Vitamin D has garnered considerable attention in the general and competitive athletic populations, primarily due to its role on various physiological systems in the body, and the effect that vitamin D deficiency has on many diseases $[113,114]$. Vitamin D has two biological forms, vitamin D3 (cholecalciferol), and vitamin D2 (ergocalciferol). Vitamin D3 is the most bioavailable and most supplemented form of Vitamin D and is synthesized in the skin upon exposure to sunlight. The specific physiological effects of vitamin D and its specific mechanisms are beyond the scope of this paper, but readers are encouraged to explore this elsewhere $[115,116]$. In brief, vitamin D, whether it is synthesized endogenously or consumed as a food or supplement, undergoes hydroxylation to become active. The first hydroxylation step occurs in the liver where vitamin D is converted to 25-hydroxyvitamin D [25(OH)D]. The second hydroxylation step is performed primarily in the kidney to form 1,25-dihydroxyvitamin D3, also referred to as 1,25-dihydroxycholecalciferol, which is the biologically active form of vitamin D $[117,118]$. The United States Institute of Medicine has indicated that the range for vitamin D concentrations should be between $25-50 \mathrm{nmol} \cdot \mathrm{L}^{-1}$ [119]. Studies on athletes have suggested that the cut-off for vitamin D deficiency should be $>30 \mathrm{nmol} \cdot \mathrm{L}^{-1}$ or even higher $[112,120,121]$.

The vitamin D receptor, which plays a central role in the biological action of the vitamin, has been observed in reproductive tissues such as the ovaries, prostate, and testes, as well as in human sperm [122-125]. Vitamin D receptors are present on the Leydig cells within the testes, where the synthesis of testosterone from cholesterol occurs [7], suggesting an important role of vitamin D on testosterone synthesis. Men with vitamin D deficiency have exhibited significantly lower testosterone concentrations compared to men with normal vitamin D concentrations [126]. Significant associations were also noted between vitamin D concentrations and circulating testosterone and SHBG concentrations, as well as the free androgen index [126]. These findings are consistent with subsequent investigations reporting significant correlations between vitamin D and testosterone concentrations [126-128].

Athletes in general are at a higher risk for vitamin D deficiency, especially athletes participating in indoor sports [121,129-131]. Vitamin D supplementation is a potential option to maintain normal vitamin $\mathrm{D}$ status, but also to potentially increase testosterone concentrations. A double-blind, randomized placebo-control trial of 54 males reported that the group receiving a daily supplementation of $83 \mu \mathrm{g}$ (3332 IU) of vitamin D for 12 months experienced significant increases in circulating 25-hydroxyvitamin D, TT, and FT concentrations compared to the placebo group [132] (described in Table 3). Although it has been suggested that the daily dose of vitamin D supplementation for athletes should be $5000 \mathrm{IU} \cdot$ day $^{-1}$ for improving performance and restoring vitamin D levels $[120,133,134]$, no consensus exists regarding the optimal range for vitamin D levels [119]. Furthermore, the effect of vitamin D supplementation on altering resting testosterone concentrations is still not well understood and requires further research.

\subsection{Zinc}

Zinc is a mineral that influences and interacts with many biological systems, especially the endocrine system [16]. Zinc has an important role in immune system function and in modulating inflammatory processes [135-138]. While zinc can be found in many food sources, the more bioavailable form of zinc can be found in animal tissues [139-142]. The daily recommended intake for zinc is between $14-40 \mathrm{mg} \cdot$ day $^{-1}$ [143]. The physiological role of zinc regarding testosterone biology is related to its requirement in the synthesis and secretion of LH. As previously discussed, LH stimulates testosterone synthesis in the Leydig cells [6,14,144]. Zinc is also important in the conversion of testosterone to DHT [144]. DHT is converted from testosterone by the enzyme $5 \alpha$-reductase in the cytoplasm of the cell. DHT is primarily found in peripheral tissues such as prostate, skin, hair follicles, and the liver $[6,145]$. As discussed earlier, DHT is thought to have a stronger androgenic affect 
than testosterone due to its four-times greater binding affinity for the androgen receptor than testosterone and a three-times slower dissociation rate than testosterone [146-148]. DHT has a vital role in the sexual development of males and sexual differentiation of organs and promotes prostate growth; male pattern baldness; and body, facial, and pubic hair growth $[6,145,149]$.

Zinc also has an indirect role in testosterone synthesis. Zinc is required for normal function of angiotensin-converting enzyme (ACE), a zinc-dependent dicarboxypeptidase, which has a zinc binding site in its cyclitic domain [150,151]. ACE is reported to increase LH production in pituitary, thus impacting androgen production [152]. Zinc deficiency can impair testosterone synthesis and has been demonstrated to correlate with reductions in testosterone concentrations [153-155]. Competitive athletes appear to be at a greater risk for zinc deficiency compared to the general population [156,157]. Considering that zinc deficiency appears to be related to hypogonadism, efforts to maintain zinc levels within normal ranges appears important. Several studies have shown that zinc supplementation can restore testosterone concentrations to their normal physiological range $[153,154,158]$. One study examined the effect of zinc supplementation on both TT and FT concentrations in healthy young adults before and after an exhaustive exercise protocol [159]. Study participants were supplemented with zinc sulfate $\left(3 \mathrm{mg} \cdot \mathrm{kg} \cdot \mathrm{day}^{-1}\right)$ for four weeks. Investigators reported that zinc supplementation increased both TT and FT concentrations prior to and following the exhaustive exercise protocol compared to pre-supplementation results. In contrast, others reported no difference in either the TT or FT response to exhaustive exercise between male cyclists supplemented with zinc sulfate $(30 \mathrm{mg})$ for four weeks compared to a placebo-controlled group [160]. Although zinc has an important role in the regulation of testosterone production, long-term studies in competitive athletes have not been conducted. Whether zinc supplementation is effective only during periods of zinc deficiency or whether it can augment normal testosterone concentrations regardless of baseline concentrations is not well understood.

\subsection{Magnesium}

Magnesium is one of the most abundant minerals in the body. It has an important role in various biological systems including protein synthesis, cellular energy production, cell growth, and reproduction [161]. From an athletic performance perspective, magnesium is involved in skeletal muscle function and energy production, suggesting a possible ergogenic effect [162]. The recommended dietary allowance for magnesium intake for men is between 400 to $420 \mathrm{mg} \cdot \mathrm{day}^{-1}$ and 310 to $320 \mathrm{mg} \cdot \mathrm{day}^{-1}$ for women [163]. Several studies have reported that athletes do not consume enough magnesium from their diet, resulting in a greater risk for magnesium deficiency [164-167]. Several investigations have reported a relationship between magnesium and testosterone concentrations [168-170]. One study indicated that magnesium supplementation in young healthy men in combination with a four-week endurance training program increased both FT and TT concentrations at rest and following exhaustive exercise [171]. An additional study conducted on nearly 400 older adult men reported a significant correlation between magnesium status and testosterone concentrations $(\mathrm{r}=0.20, p<0.05)$ [169]. The mechanism responsible for this relationship has yet to be elucidated. However, it is possible that it may be more indirect than direct. Magnesium is known to have a role in decreasing oxidative stress and inflammation [172-174]. Considering that testosterone concentrations can be strongly influenced by oxidative stress [175], it is possible that magnesium's role in decreasing oxidative stress may provide the stimulus to maintain testosterone concentrations during periods of oxidative stress. A strong positive correlation has been reported between total antioxidative capacity and testosterone concentrations $(r=0.807)$ [175]. Magnesium has an important role in maintaining antioxidant capacity and controlling oxidative stress [172-174]. Magnesium deficiency has been demonstrated to increase production of oxygen free radicals, increase oxidative tissue damage, decrease antioxidant enzyme activity, decrease cellular antioxidant levels, and increase oxygen peroxide production [176-178]. In contrast, normal 
magnesium levels can prevent oxygen radical formation by removing free radicals and inhibiting xanthine oxidase and nicotinamide adenine dinucleotide phosphate (NADPH) oxidase elevations [179].

Magnesium deficiency has also been associated with low-grade systemic inflammation $[172,180]$, and has been shown to increase pro-inflammatory cytokines: tumor necrosis factor-alpha (TNF- $\alpha$ ) and interleukin 1 (IL-1) [180-182]. Low-grade chronic inflammation has been shown to decrease testosterone concentrations by suppressing testosterone secretion from Leydig cells, resulting in both an inhibitory effect on LH secretion and reduced LH sensitivity at the Leydig cell $[183,184]$. Increases in TNF- $\alpha$ activates nuclear factor $\kappa \mathrm{B}(\mathrm{NF}-\mathrm{kB})$, a transcription factor that governs the expression of early-response genes involved in cellular responses to a wide range of signals [185]. NF- $\kappa B$ inhibits the activation of steroidogenic-enzyme genes such as Nur77 and SF-1, which regulate steroidogenesis (biosynthesis of testosterone from cholesterol) in the Leydig cells [184]. Rochelson and colleagues [186] demonstrated, through an in vitro examination, that magnesium sulfate can reduce the nuclear translocation of NF- $\mathrm{KB}$. Others have demonstrated that magnesium supplementation can reduce inflammatory status and decrease levels of TNF- $\alpha$ and IL-1 [180,187].

Magnesium also appears to reduce the binding of testosterone to SHBG [188]. Most circulating testosterone is bound to SHBG; however, the bioavailability of testosterone is related to the free testosterone concentrations, which is only a fraction of circulating testosterone [189]. Magnesium appears to bind to SHBG resulting in the blocking of testosterone's ability to bind to SHBG, subsequently enhancing testosterone bioavailability. Magnesium deficiency appears to increase testosterone binding to SHBG, potentially decreasing its bioavailability [188]. Whether magnesium supplementation is effective in augmenting testosterone synthesis as an anabolic agent is not well understood. 
Table 3. Effect of micronutrient intake on circulating testosterone concentrations.

\begin{tabular}{|c|c|c|c|c|}
\hline Source & Participants & Duration & Intervention & Key Findings \\
\hline [159] & $\begin{array}{l}n=10 \\
\text { Healthy college-aged men }\end{array}$ & 4 weeks & $\begin{array}{l}\text { - Zinc supplementation group } \\
\left(\text { zinc sulfate } 3 \mathrm{mg} \cdot \mathrm{kg} \cdot \mathrm{day}^{-1} \text { ) }\right.\end{array}$ & $\begin{array}{l}\text { - Significantly elevation of TT and FT before and after an } \\
\text { exhaustive exercise protocol compared to pre-supplementation. } \\
\text { - } \quad \text { ES before the exhaustive exercise protocol TT }=0.59 \mathrm{FT}=1.32 \\
\text { - } \quad \text { ES after the exhaustive exercise protocol TT }=0.82, \mathrm{FT}=3.32\end{array}$ \\
\hline [132] & $\begin{array}{l}n=54 \\
\text { Healthy overweight men }\end{array}$ & 12 months & $\begin{array}{ll}\text { - } & \text { Vitamin D supplementation } \\
\text { group }(n=31): 83 \mu \mathrm{g} \cdot \text { day }^{-1} \\
\text { (3332 IU) } \\
\text { - } \\
\text { Placebo group }(n=23)\end{array}$ & $\begin{array}{l}\text { - Significant increase in TT and FT in the vitamin D group } \\
\text { compared to baseline. } \\
\text { - } \quad \text { ES for TT in the VD group }=0.63 \\
\text { - } \quad \text { ES for FT in the VD group }=0.54\end{array}$ \\
\hline [160] & $\begin{array}{l}n=32 \\
\text { Male cyclists }\end{array}$ & 4 weeks & 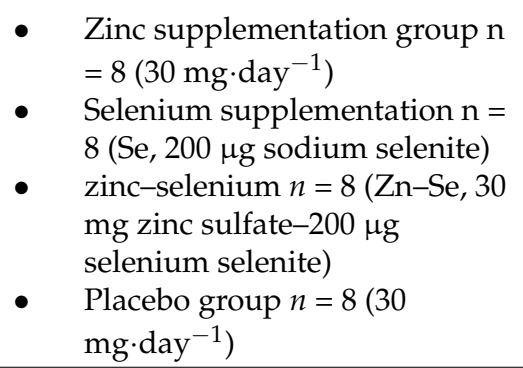 & $\begin{array}{l}\text { - No significant differences between groups for TT and FT before } \\
\text { and after the exhaustive exercise test. }\end{array}$ \\
\hline [171] & $\begin{array}{l}n=30 \\
\text { Healthy college-aged men } \\
\text { participating in an aerobic -training } \\
\text { program }\end{array}$ & 4 weeks & $\begin{array}{ll}\text { - } & \text { Magnesium supplementation + } \\
\text { training group } n=10\left(\mathrm{MgSO}_{4}\right. \\
\left.10 \mathrm{mg} \cdot \mathrm{kg} \cdot \mathrm{day}^{-1}\right) \\
\text { - } \quad \text { Magnesium supplementation } \\
\text { group only } n=10 \\
\text { Training group only } n=10\end{array}$ & 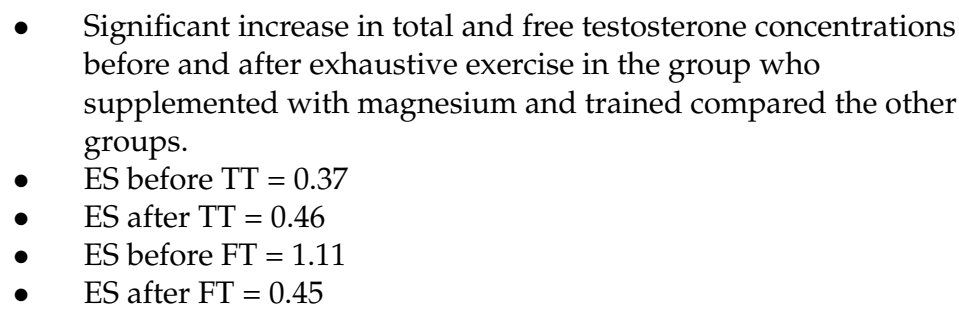 \\
\hline
\end{tabular}




\section{Summary}

In summary, this article discussed several nutrients that have been proposed to have anti-aromatase activity. Although evidence has been presented supporting the benefits of certain nutrients, the evidence supporting most of the nutrients suggested to influence anti-aromatase activity remain largely inconclusive. Much of this issue is related to the small sample sizes found in many of these papers, and the limitations that are associated with examining trained and athletic populations. More effort appears to have been focused on the effects of energy intake and manipulating macronutrient composition, specifically protein and fat composition on changes in circulating levels of testosterone at rest and in response to various exercise stresses. Evidence is consistent in demonstrating that low energy intake negatively impacts testosterone concentrations that may affect human performance. In addition, certain vitamins and minerals have important roles in testosterone synthesis. The importance of supplementing these vitamins and minerals appears to become efficacious when the body becomes deficient in these specific micronutrients. However, evidence supporting any benefits of supplementing with these micronutrients to augment testosterone concentrations is lacking.

Author Contributions: A.Z., T.B.-Z. and J.R.H. all contributed to the writing, editing and the review of this manuscript. All authors have read and agreed to the published version of the manuscript.

Funding: This research received no external funding.

Conflicts of Interest: The authors declare no conflict of interest.

\section{References}

1. Hackett, G.; Kirby, M.; Edwards, D.; Jones, T.H.; Wylie, K.; Ossei-Gerning, N.; David, J.; Muneer, A. British Society for Sexual Medicine Guidelines on Adult Testosterone Deficiency, with Statements for UK Practice. J. Sex. Med. 2017, 14, 1504-1523. [CrossRef]

2. Bhasin, S.; Hatfield, D.L.; Hoffman, J.R.; Kraemer, W.J.; Labotz, M.; Phillips, S.M.; Ratamess, N.A. Anabolic-Androgenic Steroid Use in Sports, Health, and Society. Med. Sci. Sports Exerc. 2021, 53, 1778-1794. [CrossRef]

3. Kraemer, W.J.; Ratamess, N.A.; Nindl, B.C. Recovery responses of testosterone, growth hormone, and IGF-1 after resistance exercise. J. Appl. Physiol. 2017, 122, 549-558. [CrossRef]

4. A Hiipakka, R.; Liao, S. Molecular Mechanism of Androgen Action. Trends Endocrinol. Metab. 1998, 9, 317-324. [CrossRef]

5. Ratnasabapathy, R.; Dhillo, W.S. The effects of kisspeptin in human reproductive function-Therapeutic implications. Curr. Drug Targets 2013, 14, 365-371. [PubMed]

6. Hoffman, J.R.; Kraemer, W.J.; Bhasin, S.; Storer, T.; Ratamess, N.A.; Haff, G.G.; Willoughby, D.S.; Rogol, A.D. Position stand on androgen and human growth hormone use. J. Strength Cond. Res. 2009, 23, S1-S59. [CrossRef] [PubMed]

7. O'Donnell, L.; Stanton, P.; de Kretser, D.M. Endocrinology of the Male Reproductive System and Spermatogenesis; Feingold, K.R., Anawalt, B., Boyce, A., Chrousos, G., de Herder, W.W., Dhatariya, K., Dungan, K., Grossman, A., Hershman, J.M., Hofland, J., et al., Eds.; Endotext [Internet]; MDText.com, Inc.: South Dartmouth, MA, USA, 2000.

8. Dunn, J.F.; Nisula, B.C.; Rodbard, D. Transport of Steroid Hormones: Binding of 21 Endogenous Steroids to Both TestosteroneBinding Globulin and Corticosteroid-Binding Globulin in Human Plasma. J. Clin. Endocrinol. Metab. 1981, 53, 58-68. [CrossRef] [PubMed]

9. Hoffman, J.R. Testosterone: A review of exercise responses and physiological effects. NSCA Journal. 1992, 14, $10-17$.

10. Breiner, M.; Romalo, G.; Schweikert, H.-U. Inhibition of androgen receptor binding by natural and synthetic steroids in cultured human genital skin fibroblasts. J. Mol. Med. 1986, 64, 732-737. [CrossRef]

11. Kraemer, W.J.; Ratamess, N.A.; Hymer, W.C.; Nindl, B.C.; Fragala, M.S. Growth Hormone(s), Testosterone, Insulin-Like Growth Factors, and Cortisol: Roles and Integration for Cellular Development and Growth with Exercise. Front. Endocrinol. $2020,11,33$. [CrossRef]

12. Bennett, N.C.; Gardiner, R.A.; Hooper, J.; Johnson, D.; Gobe, G.C. Molecular cell biology of androgen receptor signalling. Int. J. Biochem. Cell Biol. 2010, 42, 813-827. [CrossRef]

13. Hooper, D.R.; Kraemer, W.J.; Saenz, C.; Schill, K.E.; Focht, B.C.; Volek, J.S.; Maresh, C.M. The presence of symptoms of testosterone deficiency in the exercise-hypogonadal male condition and the role of nutrition. Eur. J. Appl. Physiol. 2017, 117, 1349-1357. [CrossRef]

14. Wrzosek, M.; Woźniak, J.; Włodarek, D. The causes of adverse changes of testosterone levels in men. Expert Rev. Endocrinol. Metab. 2020, 15, 355-362. [CrossRef]

15. Fantus, R.J.; Halpern, J.A.; Chang, C.; Keeter, M.K.; Bennett, N.E.; Helfand, B.; Brannigan, R.E. The Association between Popular Diets and Serum Testosterone among Men in the United States. J. Urol. 2020, 203, 398-404. [CrossRef] 
16. Baltaci, A.K.; Mogulkoc, R.; Baltaci, S.B. Review: The role of zinc in the endocrine system. Pak. J. Pharm. Sci. 2019, 32, 231-239. [PubMed]

17. Van Kiem, P.; Dat, N.T.; Van Minh, C.; Lee, J.J.; Kim, Y.H. Lupane-triterpenes from the leaves of Brassaiopsis glomerulata. Arch. Pharmacal Res. 2003, 26, 594-596. [CrossRef] [PubMed]

18. Balunas, M.J.; Su, B.; Riswan, S.; Fong, H.H.; Brueggemeier, R.W.; Pezzuto, J.M.; Kinghorn, A.D. Isolation and characterization of aromatase inhibitors from Brassaiopsis glomerulata (Araliaceae). Phytochem. Lett. 2009, 2, 29-33. [CrossRef]

19. Kowalska, M.T.; Itzhak, Y.; Puett, D. Presence of aromatase inhibitors in cycads. J. Ethnopharmacol. 1995, 47, 113-116. [CrossRef]

20. Hargrove, J.L.; Greenspan, P.; Hartle, D.K.; Dowd, C. Inhibition of Aromatase and $\alpha$-Amylase by Flavonoids and Proanthocyanidins from Sorghum bicolor Bran Extracts. J. Med. Food 2011, 14, 799-807. [CrossRef] [PubMed]

21. Kim, H.K.; Whang, W.K.; Kim, I.H. Constituents of the herb ofIsodon excisus var.coreanus. Arch. Pharmacal Res. 1997, 20, 291-296. [CrossRef] [PubMed]

22. Jeong, H.-J.; Chang, L.C.; Kim, H.-K.; Kim, I.-H.; Kinghorn, A.D.; Pezzuto, J.M. Aromatase inhibitors fromIsodon excisus var.coreanus. Arch. Pharmacal Res. 2000, 23, 243-245. [CrossRef] [PubMed]

23. Lee, T.; Kim, D.; Han, J.; Kim, C. Inhibitory Effects of Scutellaria Barbata D. Don. and Euonymus Alatus Sieb. on Aromatase Activity of Human Leiomyomal Cells. Immunopharmacol. Immunotoxicol. 2004, 26, 315-327. [CrossRef] [PubMed]

24. Golan, R.; Gepner, Y.; Shai, I. Wine and Health-New Evidence. Eur. J. Clin. Nutr. 2019, 72, 55-59. [CrossRef]

25. Eng, E.T.; Ye, J.; Williams, D.; Phung, S.; Moore, R.; Young, M.K.; Gruntmanis, U.; Braunstein, G.; Chen, S. Suppression of estrogen biosynthesis by procyanidin dimers in red wine and grape seeds. Cancer Res. 2003, 63, 8516-8522.

26. Eng, E.T.; Williams, D.; Mandava, U.; Kirma, N.; Tekmal, R.R.; Chen, S. Anti-aromatase chemicals in red wine. Ann. N. Y. Acad. Sci. 2006, 963, 239-246. [CrossRef]

27. Eng, E.T.; Williams, D.; Mandava, U.; Kirma, N.; Tekmal, R.R.; Chen, S. Suppression of aromatase (estrogen synthetase) by red wine phytochemicals. Breast Cancer Res. Treat. 2001, 67, 133-146. [CrossRef]

28. Kijima, I.; Phung, S.; Hur, G.; Kwok, S.-L.; Chen, S. Grape Seed Extract Is an Aromatase Inhibitor and a Suppressor of Aromatase Expression. Cancer Res. 2006, 66, 5960-5967. [CrossRef]

29. Shufelt, C.; Merz, C.N.B.; Yang, Y.; Kirschner, J.; Polk, D.; Stanczyk, F.; Paul-Labrador, M.; Braunstein, G.D. Red Versus White Wine as a Nutritional Aromatase Inhibitor in Premenopausal Women: A Pilot Study. J. Women's Health 2012, 21, 281-284. [CrossRef] [PubMed]

30. Ren, Z.; Guo, Z.; Meydani, S.N.; Wu, D. White Button Mushroom Enhances Maturation of Bone Marrow-Derived Dendritic Cells and Their Antigen Presenting Function in Mice. J. Nutr. 2008, 138, 544-550. [CrossRef]

31. Rop, O.; Mlcek, J.; Juríková, T. Beta-glucans in higher fungi and their health effects. Nutr. Rev. 2009, 67, 624-631. [CrossRef] [PubMed]

32. Grube, B.J.; Eng, E.T.; Kao, Y.-C.; Kwon, A.; Chen, S. White button mushroom phytochemicals inhibit aromatase activity and breast cancer cell proliferation. J. Nutr. 2001, 131, 3288-3293. [CrossRef]

33. Loing, E.; Lachance, R.; Ollier, V.; Hocquaux, M. A new strategy to modulate alopecia using a combination of two specific and unique ingredients. J. Cosmet. Sci. 2013, 64, 45-58.

34. Lipovac, M.; Chedraui, P.; Gruenhut, C.; Gocan, A.; Kurz, C.; Neuber, B.; Imhof, M. Effect of Red Clover Isoflavones over Skin, Appendages, and Mucosal Status in Postmenopausal Women. Obstet. Gynecol. Int. 2011, 2011, 1-6. [CrossRef]

35. Almstrup, K.; Fernandez, M.F.; Petersen, J.H.; Olea, N.; Skakkebaek, N.E.; Leffers, H. Dual effects of phytoestrogens result in u-shaped dose-response curves. Environ. Health Perspect. 2002, 110, 743-748. [CrossRef]

36. Balunas, M.; Su, B.; Brueggemeier, R.W.; Kinghorn, A.D. Xanthones from the Botanical Dietary Supplement Mangosteen (Garcinia mangostana) with Aromatase Inhibitory Activity. J. Nat. Prod. 2008, 71, 1161-1166. [CrossRef] [PubMed]

37. Konda, M.R.; Alluri, K.V.; Janardhanan, P.K.; Trimurtulu, G.; Sengupta, K. Combined extracts of Garcinia mangostana fruit rind and Cinnamomum tamala leaf supplementation enhances muscle strength and endurance in resistance trained males. J. Int. Soc. Sports Nutr. 2018, 15, 50. [CrossRef]

38. Sultan, C.; Terraza, A.; Devillier, C.; Carilla, E.; Briley, M.; Loire, C.; Descomps, B. Inhibition of androgen metabolism and binding by a liposterolic extract of "serenoa repens B" in human foreskin fibroblasts. J. Steroid Biochem. 1984, 20, 515-519. [CrossRef]

39. Sudeep, H.V.; Thomas, J.V.; Shyamprasad, K. A double blind, placebo-controlled randomized comparative study on the efficacy of phytosterol-enriched and conventional saw palmetto oil in mitigating benign prostate hyperplasia and androgen deficiency. BMC Urol. 2020, 20, 1-11. [CrossRef] [PubMed]

40. Angwafor, F.; Anderson, M.L. An open label, dose response study to determine the effect of a dietary supplement on dihydrotestosterone, testosterone and estradiol levels in healthy males. J. Int. Soc. Sports Nutr. 2008, 5, 12. [CrossRef]

41. Osawa, Y.; Tochigi, B.; Tochigi, M.; Ohnishi, S.; Watanabe, Y.; Bullion, K.; Osawa, G.; Nakabayashi, Y.; Yarborough, C. Aromatase Inhibitors in Cigarette Smoke, Tobacco Leaves and Other Plants. J. Enzym. Inhib. 1990, 4, 187-200. [CrossRef]

42. Panche, A.N.; Diwan, A.D.; Chandra, S.R. Flavonoids: An overview. J. Nutr. Sci. 2016, 5, e47. [CrossRef]

43. Hatti, K.S.; Diwakar, L.; Rao, G.V.; Kush, A.; Reddy, G.C. Abyssinones and related flavonoids as potential steroidogenesis modulators. Bioinformation 2009, 3, 399-402. [CrossRef]

44. Bors, W.; Michel, C.; Stettmaier, K. Antioxidant effects of flavonoids. BioFactors 1997, 6, 399-402. [CrossRef] 
45. Arango, D.; Morohashi, K.; Yilmaz, A.; Kuramochi, K.; Parihar, A.; Brahimaj, B.; Grotewold, E.; Doseff, A.I. Molecular basis for the action of a dietary flavonoid revealed by the comprehensive identification of apigenin human targets. Proc. Natl. Acad. Sci. USA 2013, 110, E2153-E2162. [CrossRef]

46. Monteiro, R.; Becker, H.; Azevedo, I.; Calhau, C. Effect of Hop (Humulus lupulus L.) Flavonoids on Aromatase (Estrogen Synthase) Activity. J. Agric. Food Chem. 2006, 54, 2938-2943. [CrossRef]

47. Tomas-Barberán, F.A.; Cienfuegos-Jovellanos, E.; Marín, A.; Muguerza, B.; Gil-Izquierdo, A.; Cerdá, B.; Zafrilla, P.; Morillas, J.; Mulero, J.; Ibarra, A.; et al. A New Process to Develop a Cocoa Powder with Higher Flavonoid Monomer Content and Enhanced Bioavailability in Healthy Humans. J. Agric. Food Chem. 2007, 55, 3926-3935. [CrossRef] [PubMed]

48. Chou, H.-C.; Šuklje, K.; Antalick, G.; Schmidtke, L.M.; Blackman, J.W. Late-Season Shiraz Berry Dehydration That Alters Composition and Sensory Traits of Wine. J. Agric. Food Chem. 2018, 66, 7750-7757. [CrossRef] [PubMed]

49. Pacheco-Palencia, L.A.; Mertens-Talcott, S.; Talcott, S.T. Chemical composition, antioxidant properties, and thermal stability of a phytochemical enriched oil from Acai (Euterpe oleracea Mart.). J. Agric. Food Chem. 2008, 56, 4631-4636. [CrossRef] [PubMed]

50. Neves, M.A.C.; Dinis, T.C.P.; Colombo, G.; e Melo, M.L.S. Combining Computational and Biochemical Studies for a Rationale on the Anti-Aromatase Activity of Natural Polyphenols. ChemMedChem 2007, 2, 1750-1762. [CrossRef] [PubMed]

51. Kao, Y.C.; Zhou, C.; Sherman, M.; Laughton, C.A.; Chen, S. Molecular basis of the inhibition of human aromatase (estrogen synthetase) by flavone and isoflavone phytoestrogens: A site-directed mutagenesis study. Environ. Health Perspect 1998, 106, 85-92. [CrossRef]

52. Kellis, J.; Vickery, L. Inhibition of human estrogen synthetase (aromatase) by flavones. Science 1984, 225, 1032-1034. [CrossRef]

53. Gambelunghe, C.; Rossi, R.; Sommavilla, M.; Ferranti, C.; Rossi, R.; Ciculi, C.; Gizzi, S.; Micheletti, A.; Rufini, S. Effects of Chrysin on Urinary Testosterone Levels in Human Males. J. Med. Food 2003, 6, 387-390. [CrossRef]

54. Brown, G.A.; Vukovich, M.D.; Martini, E.R.; Kohut, M.L.; Franke, W.D.; Jackson, D.A.; King, D.S. Effects of AndrostenedioneHerbal Supplementation on Serum Sex Hormone Concentrations in 30- to 59-Year-old Men. Int. J. Vitam. Nutr. Res. 2001, 71, 293-301. [CrossRef]

55. Nielsen, F.H.; Hunt, C.D.; Mullen, L.M.; Hunt, J.R. Effect of dietary boron on mineral, estrogen, and testosterone metabolism in postmenopausal women 1. FASEB J. 1987, 1, 394-397. [CrossRef] [PubMed]

56. Naghii, M.R.; Samman, S. The effect of boron supplementation on its urinary excretion and selected cardiovascular risk factors in healthy male subjects. Biol. Trace Elem. Res. 1997, 56, 273-286. [CrossRef] [PubMed]

57. Green, N.R.; Ferrando, A.A. Plasma boron and the effects of boron supplementation in males. Environ. Health Perspect. 1994, 102 (Suppl. 7), 73-77. [PubMed]

58. Naghii, M.; Samman, S. The effect of boron on plasma testosterone and plasma lipids in rats. Nutr. Res. 1997, 17, 523-531. [CrossRef]

59. Naghii, M.R.; Mofid, M.; Asgari, A.R.; Hedayati, M.; Daneshpour, M.A. Comparative effects of daily and weekly boron supplementation on plasma steroid hormones and proinflammatory cytokines. J. Trace Elem. Med. Biol. 2011, 25, 54-58. [CrossRef]

60. Rainey, C.J.; A Nyquist, L.; E Christensen, R.; Strong, P.L.; Culver, B.D.; Coughlin, J.R. Daily Boron Intake from the American Diet. J. Am. Diet. Assoc. 1999, 99, 335-340. [CrossRef]

61. Starks, M.A.; Starks, S.L.; Kingsley, M.; Purpura, M.; Jäger, R. The effects of phosphatidylserine on endocrine response to moderate intensity exercise. J. Int. Soc. Sports Nutr. 2008, 5, 11. [CrossRef]

62. Hoffman, J.R.; Stout, J.R.; Williams, D.R.; Wells, A.J.; Fragala, M.S.; Mangine, G.T.; Gonzalez, A.M.; Emerson, N.S.; McCormack, W.P.; Scanlon, T.C.; et al. Efficacy of phosphatidic acid ingestion on lean body mass, muscle thickness and strength gains in resistance-trained men. J. Int. Soc. Sports Nutr. 2012, 9, 47. [CrossRef]

63. Balasubramanian, A.; Thirumavalavan, N.; Srivatsav, A.; Yu, J.; Lipshultz, L.I.; Pastuszak, A.W. Testosterone Imposters: An Analysis of Popular Online Testosterone Boosting Supplements. J. Sex. Med. 2019, 16, 203-212. [CrossRef]

64. Clemesha, C.G.; Thaker, H.; Samplaski, M.K. 'Testosterone Boosting' Supplements Composition and Claims Are not Supported by the Academic Literature. World J. Men's Health 2020, 38, 115-122. [CrossRef] [PubMed]

65. Kavvoura, A.; Zaras, N.; Stasinaki, A.-N.; Arnaoutis, G.; Methenitis, S.; Terzis, G. The Importance of Lean Body Mass for the Rate of Force Development in Taekwondo Athletes and Track and Field Throwers. J. Funct. Morphol. Kinesiol. 2018, 3, 43. [CrossRef] [PubMed]

66. Zaras, N.; Stasinaki, A.-N.; Spiliopoulou, P.; Hadjicharalambous, M.; Terzis, G. Lean Body Mass, Muscle Architecture, and Performance in Well-Trained Female Weightlifters. Sports 2020, 8, 67. [CrossRef] [PubMed]

67. Sundgot-Borgen, J.; Torstveit, M.K. Aspects of disordered eating continuum in elite high-intensity sports. Scand. J. Med. Sci. Sports 2010, 20, 112-121. [CrossRef] [PubMed]

68. Wasserfurth, P.; Palmowski, J.; Hahn, A.; Krüger, K. Reasons for and Consequences of Low Energy Availability in Female and Male Athletes: Social Environment, Adaptations, and Prevention. Sports Med. Open 2020, 6, 1-14. [CrossRef]

69. Mountjoy, M.; Sundgot-Borgen, J.K.; Burke, L.M.; Ackerman, K.E.; Blauwet, C.; Constantini, N.; Lebrun, C.; Lundy, B.; Melin, A.K.; Meyer, N.L.; et al. IOC consensus statement on relative energy deficiency in sport (RED-S): 2018 update. Br. J. Sports Med. 2018, 52, 687-697. [CrossRef]

70. Melin, A.K.; Heikura, I.; Tenforde, A.; Mountjoy, M. Energy Availability in Athletics: Health, Performance, and Physique. Int. J. Sport Nutr. Exerc. Metab. 2019, 29, 152-164. [CrossRef] 
71. Egger, T.; Flueck, J.L. Energy Availability in Male and Female Elite Wheelchair Athletes over Seven Consecutive Training Days. Nutr. 2020, 12, 3262. [CrossRef]

72. Loucks, A.B.; Heath, E.M. Dietary restriction reduces luteinizing hormone (LH) pulse frequency during waking hours and increases LH pulse amplitude during sleep in young menstruating women. J. Clin. Endocrinol. Metab. 1994, 78, 910-915. [CrossRef] [PubMed]

73. Loucks, A.B.; Verdun, M. Slow restoration of LH pulsatility by refeeding in energetically disrupted women. Am. J. Physiol. Integr. Comp. Physiol. 1998, 275, R1218-R1226. [CrossRef] [PubMed]

74. Loucks, A.B.; Thuma, J.R. Luteinizing Hormone Pulsatility Is Disrupted at a Threshold of Energy Availability in Regularly Menstruating Women. J. Clin. Endocrinol. Metab. 2003, 88, 297-311. [CrossRef] [PubMed]

75. Hu, T.-Y.; Chen, Y.C.; Lin, P.; Shih, C.-K.; Bai, C.-H.; Yuan, K.-C.; Lee, S.-Y.; Chang, J.-S. Testosterone-Associated Dietary Pattern Predicts Low Testosterone Levels and Hypogonadism. Nutrients 2018, 10, 1786. [CrossRef]

76. Henning, P.C.; Margolis, L.M.; McClung, J.P.; Young, A.J.; Pasiakos, S.M. High protein diets do not attenuate decrements in testosterone and IGF-I during energy deficit. Metabolism 2014, 63, 628-632. [CrossRef]

77. Hooper, D.R.; Tenforde, A.S.; Hackney, A.C. Treating exercise-associated low testosterone and its related symptoms. Physician Sportsmed. 2018, 46, 427-434. [CrossRef]

78. Mäestu, J.; Eliakim, A.; Jürimäe, J.; Valter, I.; Jürimäe, T. Anabolic and Catabolic Hormones and Energy Balance of the Male Bodybuilders During the Preparation for the Competition. J. Strength Cond. Res. 2010, 24, 1074-1081. [CrossRef]

79. Heikura, I.A.; Uusitalo, A.L.T.; Stellingwerff, T.; Bergland, D.; Mero, A.A.; Burke, L.M. Low Energy Availability Is Difficult to Assess but Outcomes Have Large Impact on Bone Injury Rates in Elite Distance Athletes. Int. J. Sport Nutr. Exerc. Metab. 2018, 28, 403-411. [CrossRef]

80. Torstveit, M.K.; Fahrenholtz, I.; Stenqvist, T.B.; Sylta, Ø.; Melin, A. Within-Day Energy Deficiency and Metabolic Perturbation in Male Endurance Athletes. Int. J. Sport Nutr. Exerc. Metab. 2018, 28, 419-427. [CrossRef]

81. Lichtenstein, A.H.; Kennedy, E.; Barrier, P.; Danford, D.; Ernst, N.D.; Grundy, S.M.; Leveille, G.A.; Horn, L.; Williams, C.L.; Booth, S.L. Dietary Fat Consumption and Health. Nutr. Rev. 2009, 56, 3-19. [CrossRef]

82. Trumbo, P.; Schlicker, S.; Yates, A.A.; Poos, M. Food and Nutrition Board of the Institute of Medicine TeNA: Dietary reference intakes for energy, carbohydrate, fiber, fat, fatty acids, cholesterol, protein and amino acids. J. Am. Diet. Assoc. 2002, 102, 1621-1630. [CrossRef]

83. Mota, J.A.; Nuckols, G.; Smith-Ryan, A.E. Nutritional Periodization: Applications for the Strength Athlete. Strength Cond. J. 2019, 41, 69-78. [CrossRef]

84. Aranceta, J.; Pérez-Rodrigo, C. Recommended dietary reference intakes, nutritional goals and dietary guidelines for fat and fatty acids: A systematic review. Br. J. Nutr. 2012, 107, S8-S22. [CrossRef]

85. Whittaker, J.; Wu, K. Low-fat diets and testosterone in men: Systematic review and meta-analysis of intervention studies. J. Steroid Biochem. Mol. Biol. 2021, 210, 105878. [CrossRef] [PubMed]

86. Wilson, J.M.; Lowery, R.P.; Roberts, M.D.; Sharp, M.H.; Joy, J.M.; Shields, K.A.; Partl, J.; Volek, J.S.; D'Agostino, D. The Effects of Ketogenic Dieting on Body Composition, Strength, Power, and Hormonal Profiles in Resistance Training Males. J. Strength Cond. Res. 2020, 34, 3463-3474. [CrossRef]

87. Volek, J.S.; Kraemer, W.J.; Bush, J.A.; Incledon, T.; Boetes, M. Testosterone and cortisol in relationship to dietary nutrients and resistance exercise. J. Appl. Physiol. 1997, 82, 49-54. [CrossRef]

88. Santos, H.O. Ketogenic diet and testosterone increase: Is the increased cholesterol intake responsible? To what extent and under what circumstances can there be benefits? Hormones 2017, 16, 266-270. [CrossRef]

89. Goldin, B.R.; Woods, M.N.; Spiegelman, D.L.; Longcope, C.; Morrill-LaBrode, A.; Dwyer, J.; Gualtieri, L.J.; Hertzmark, E.; Gorbach, S.L. The effect of dietary fat and fiber on serum estrogen concentrations in premenopausal women under controlled dietary conditions. Cancer 1994, 74, 1125-1131. [CrossRef]

90. Helge, J.W. A high carbohydrate diet remains the evidence based choice for elite athletes to optimise performance. J. Physiol. 2017, 595, 2775. [CrossRef] [PubMed]

91. Vigh-Larsen, J.F.; Ørtenblad, N.; Spriet, L.L.; Overgaard, K.; Mohr, M. Muscle Glycogen Metabolism and High-Intensity Exercise Performance: A Narrative Review. Sports Med. 2021, 51, 1855-1874. [CrossRef] [PubMed]

92. Burke, L.M. Re-Examining High-Fat Diets for Sports Performance: Did We Call the 'Nail in the Coffin' Too Soon? Sports Med. 2015, 45, 33-49. [CrossRef]

93. Taber, C.B.; Vigotsky, A.; Nuckols, G.; Haun, C.T. Exercise-Induced Myofibrillar Hypertrophy is a Contributory Cause of Gains in Muscle Strength. Sports Med. 2019, 49, 993-997. [CrossRef]

94. Slater, G.J.; Dieter, B.P.; Marsh, D.J.; Helms, E.R.; Shaw, G.; Iraki, J. Is an Energy Surplus Required to Maximize Skeletal Muscle Hypertrophy Associated With Resistance Training. Front. Nutr. 2019, 6, 131. [CrossRef]

95. Morton, R.W.; McGlory, C.; Phillips, S.M. Nutritional interventions to augment resistance training-induced skeletal muscle hypertrophy. Front. Physiol. 2015, 6, 245. [CrossRef]

96. Jäger, R.; Kerksick, C.M.; Campbell, B.I.; Cribb, P.J.; Wells, S.D.; Skwiat, T.M.; Purpura, M.; Ziegenfuss, T.N.; Ferrando, A.A.; Arent, S.M.; et al. International Society of Sports Nutrition Position Stand: Protein and exercise. J. Int. Soc. Sports Nutr. 2017, 14, 20. [CrossRef] 
97. Stokes, T.; Hector, A.J.; Morton, R.W.; McGlory, C.; Phillips, S.M. Recent Perspectives Regarding the Role of Dietary Protein for the Promotion of Muscle Hypertrophy with Resistance Exercise Training. Nutrients 2018, 10, 180. [CrossRef]

98. 98. Morton, R.W.; Murphy, K.T.; McKellar, S.R.; Schoenfeld, B.J.; Henselmans, M.; Helms, E.; Aragon, A.A.; Devries, M.C.; Banfield, L.; Krieger, J.W.; et al. A systematic review, meta-analysis and meta-regression of the effect of protein supplementation on resistance training-induced gains in muscle mass and strength in healthy adults. Br. J. Sports Med. 2018, 52, 376-384. [CrossRef] [PubMed]

99. Candow, D.G.; Burke, N.C.; Smith-Palmer, T.; Burke, D.G. Effect of whey and soy protein supplementation combined with resistance training in young adults. Int. J. Sport Nutr. Exerc. Metab. 2006, 16, 233-244. [CrossRef] [PubMed]

100. Messina, M.; Nagata, C.; Wu, A.H. Estimated Asian Adult Soy Protein and Isoflavone Intakes. Nutr. Cancer 2006, 55, 1-12. [CrossRef] [PubMed]

101. Kuiper, G.G.; Carlsson, B.; Grandien, K.; Enmark, E.; Häggblad, J.; Nilsson, S.; Gustafsson, J.A. Comparison of the ligand binding specificity and transcript tissue distribution of estrogen receptors alpha and beta. Endocrinology 1997, 138, 863-870. [CrossRef] [PubMed]

102. Kuiper, G.G.; Lemmen, J.G.; Carlsson, B.; Corton, J.C.; Safe, S.H.; van der Saag, P.T.; van der Burg, B.; Gustafsson, J.A. Interaction of estrogenic chemicals and phytoestrogens with estrogen receptor beta. Endocrinology 1998, 139, 4252-4263. [CrossRef] [PubMed]

103. Weber, K.; Setchell, K.; Stocco, D.; Lephart, E.; Weber, S. Dietary soy-phytoestrogens decrease testosterone levels and prostate weight without altering LH, prostate 5alpha-reductase or testicular steroidogenic acute regulatory peptide levels in adult male Sprague-Dawley rats. J. Endocrinol. 2001, 170, 591-599. [CrossRef] [PubMed]

104. Strauss, L.; Mäkelä, S.; Joshi, S.; Huhtaniemi, I.; Santti, R. Genistein exerts estrogen-like effects in male mouse reproductive tract. Mol. Cell. Endocrinol. 1998, 144, 83-93. [CrossRef]

105. Kwon, S.M.; Kim, S.I.; Chun, D.C.; Cho, N.H.; Chung, B.C.; Park, B.W.; Hong, S.J. Development of Rat Prostatitis Model by Oral Administration of Isoflavone and Its Characteristics. Yonsei Med. J. 2001, 42, 395-404. [CrossRef]

106. Roberts, D.; Veeramachaneni, D.N.R.; Schlaff, W.D.; Awoniyi, C.A. Effects of Chronic Dietary Exposure to Genistein, a Phytoestrogen, During Various Stages of Development on Reproductive Hormones and Spermatogenesis in Rats. Endocrine 2000, 13, 281-286. [CrossRef]

107. Hamilton-Reeves, J.M.; Vazquez, G.; Duval, S.J.; Phipps, W.R.; Kurzer, M.S.; Messina, M.J. Clinical studies show no effects of soy protein or isoflavones on reproductive hormones in men: Results of a meta-analysis. Fertil. Steril. 2010, 94, 997-1007. [CrossRef]

108. Kraemer, W.J.; Solomon-Hill, G.; Volk, B.M.; Kupchak, B.R.; Looney, D.P.; Dunn-Lewis, C.; Comstock, B.A.; Szivak, T.K.; Hooper, D.R.; Flanagan, S.D.; et al. The effects of soy and whey protein supplementation on acute hormonal reponses to resistance exercise in men. J. Am. Coll. Nutr. 2013, 32, 66-74. [CrossRef]

109. Haun, C.T.; Mobley, C.B.; Vann, C.G.; Romero, M.A.; Roberson, P.A.; Mumford, P.W.; Kephart, W.C.; Healy, J.C.; Patel, R.K.; Osburn, S.C.; et al. Soy protein supplementation is not androgenic or estrogenic in college-aged men when combined with resistance exercise training. Sci. Rep. 2018, 8, 11151. [CrossRef]

110. Kalman, D.; Feldman, S.; Martinez, M.; Krieger, D.R.; Tallon, M.J. Effect of protein source and resistance training on body composition and sex hormones. J. Int. Soc. Sports Nutr. 2007, 4, 4. [CrossRef]

111. Vidić, V.; Ilić, V.; Toskić, L.; Janković, N.; Ugarković, D. Effects of calorie restricted low carbohydrate high fat ketogenic vs. non-ketogenic diet on strength, body-composition, hormonal and lipid profile in trained middle-aged men. Clin. Nutr. 2021, 40, 1495-1502. [CrossRef]

112. Bendik, I.; Friedel, A.; Roos, F.F.; Weber, P.; Eggersdorfer, M. Vitamin D: A critical and essential micronutrient for human health. Front. Physiol. 2014, 5, 248. [CrossRef]

113. Zhang, R.; Naughton, D.P. Vitamin D in health and disease: Current perspectives. Nutr. J. 2010, 9, 65. [CrossRef]

114. Holick, M.F.; Binkley, N.C.; Bischoff-Ferrari, H.; Gordon, C.M.; Hanley, D.A.; Heaney, R.P.; Murad, M.H.; Weaver, C.M. Guidelines for Preventing and Treating Vitamin D Deficiency and Insufficiency Revisited. J. Clin. Endocrinol. Metab. 2012, 97, 1153-1158. [CrossRef]

115. Bikle, D.D. Vitamin D Metabolism, Mechanism of Action, and Clinical Applications. Chem. Biol. 2014, 21, 319-329. [CrossRef] [PubMed]

116. de la Puente Yagüe, M.; Collado Yurrita, L.; Cuadrado Cenzual, M.A. Faculty Opinions recommendation of Role of vitamin D in athletes and their performance: Current concepts and new trends. Fac. Opin. Post-Publ. Peer Rev. Biomed. Lit. 2020, $12,579$. [CrossRef]

117. Lips, P. Vitamin D physiology. Prog. Biophys. Mol. Biol. 2006, 92, 4-8. [CrossRef]

118. Tripkovic, L.; Lambert, H.; Hart, K.; Smith, C.P.; Bucca, G.; Penson, S.; Chope, G.; Hypponen, E.; Berry, J.; Vieth, R.; et al. Comparison of vitamin D2 and vitamin D3 supplementation in raising serum 25-hydroxyvitamin D status: A systematic review and meta-analysis. Am. J. Clin. Nutr. 2012, 95, 1357-1364. [CrossRef] [PubMed]

119. Ross, A.C.; Manson, J.E.; Abrams, S.A.; Aloia, J.F.; Brannon, P.M.; Clinton, S.K.; Durazo-Arvizu, R.A.; Gallagher, J.C.; Gallo, R.L.; Jones, G.; et al. The 2011 Report on Dietary Reference Intakes for Calcium and Vitamin D from the Institute of Medicine: What Clinicians Need to Know. J. Clin. Endocrinol. Metab. 2011, 96, 53-58. [CrossRef]

120. Jung, H.C.; Seo, M.W.; Lee, S.; Jung, S.W.; Song, J.K. Correcting Vitamin D Insufficiency Improves Some But Not All Aspects of Physical Performance During Winter Training in Taekwondo Athletes. Int. J. Sport Nutr. Exerc. Metab. 2018, 28, 635-643. [CrossRef] 
121. Farrokhyar, F.; Tabasinejad, R.; Dao, D.; Peterson, D.; Ayeni, O.R.; Hadioonzadeh, R.; Bhandari, M. Prevalence of Vitamin D Inadequacy in Athletes: A Systematic-Review and Meta-Analysis. Sports Med. 2015, 45, 365-378. [CrossRef]

122. Habib, F.; Maddy, S.; Gelly, K. Characterisation of receptors for 1,25-dihydroxyvitamin D3 in the human testis. J. Steroid Biochem. 1990, 35, 195-199. [CrossRef]

123. Johnson, J.A.; Grande, J.P.; Roche, P.C.; Kumar, R. Immunohistochemical detection and distribution of the 1,25-dihydroxyvitamin D3 receptor in rat reproductive tissues. Histochem. Cell Biol. 1996, 105, 7-15. [CrossRef]

124. Aquila, S.; Guido, C.; Perrotta, I.; Tripepi, S.; Nastro, A.; Andò, S. Human sperm anatomy: Ultrastructural localization of $1 \alpha, 25$-dihydroxyvitamin D3 receptor and its possible role in the human male gamete. J. Anat. 2008, 213, 555-564. [CrossRef]

125. Wang, Y.; Zhu, J.; DeLuca, H.F. Where is the vitamin D receptor? Arch. Biochem. Biophys. 2012, 523, 123-133. [CrossRef] [PubMed]

126. Wehr, E.; Pilz, S.; Boehm, B.O.; MãRz, W.; Obermayer-Pietsch, B. Association of vitamin D status with serum androgen levels in men. Clin. Endocrinol. 2009, 73, 243-248. [CrossRef]

127. Lee, D.M.; Tajar, A.; Pye, S.R.; Boonen, S.; Vanderschueren, D.; Bouillon, R.; O’Neill, T.W.; Bartfai, G.; Casanueva, F.F.; Finn, J.D.; et al. Association of hypogonadism with vitamin D status: The European Male Ageing Study. Eur. J. Endocrinol. 2012, 166, 77-85. [CrossRef] [PubMed]

128. Nimptsch, K.; Platz, E.A.; Willett, W.C.; Giovannucci, E. Association between plasma 25-OH vitamin D and testosterone levels in men. Clin. Endocrinol. 2012, 77, 106-112. [CrossRef]

129. Close, G.; Russell, J.; Cobley, J.; Owens, D.; Wilson, G.; Gregson, W.; Fraser, W.; Morton, J. Assessment of vitamin D concentration in non-supplemented professional athletes and healthy adults during the winter months in the UK: Implications for skeletal muscle function. J. Sports Sci. 2013, 31, 344-353. [CrossRef]

130. Farrokhyar, F.; Sivakumar, G.K.; Savage, K.; Koziarz, A.; Jamshidi, S.; Ayeni, O.R.; Peterson, D.; Bhandari, M. Effects of Vitamin D Supplementation on Serum 25-Hydroxyvitamin D Concentrations and Physical Performance in Athletes: A Systematic Review and Meta-analysis of Randomized Controlled Trials. Sports Med. 2017, 47, 2323-2339. [CrossRef] [PubMed]

131. Dubnov-Raz, G.; Livne, N.; Raz, R.; Cohen, A.H.; Constantini, N.W. Vitamin D Supplementation and Physical Performance in Adolescent Swimmers. Int. J. Sport Nutr. Exerc. Metab. 2015, 25, 317-325. [CrossRef]

132. Pilz, S.; Frisch, S.; Koertke, H.; Kuhn, J.; Dreier, J.; Obermayer-Pietsch, B.; Wehr, E.; Zittermann, A. Effect of Vitamin D Supplementation on Testosterone Levels in Men. Horm. Metab. Res. 2010, 43, 223-225. [CrossRef]

133. Dahlquist, D.T.; Dieter, B.P.; Koehle, M.S. Plausible ergogenic effects of vitamin D on athletic performance and recovery. J. Int. Soc. Sports Nutr. 2015, 12, 1-12. [CrossRef]

134. He, C.-S.; Fraser, W.D.; Tang, J.; Brown, K.; Renwick, S.; Rudland-Thomas, J.; Teah, J.; Tanqueray, E.; Gleeson, M. The effect of 14 weeks of vitamin D 3 supplementation on antimicrobial peptides and proteins in athletes. J. Sports Sci. 2015, 34, 1-8. [CrossRef]

135. 135. Micheletti, A.; Rossi, R.; Rufini, S. Zinc status in athletes: Relation to diet and exercise. Sports Med. 2001, 31, 577-582. [CrossRef] [PubMed]

136. Miranda, E.R.; Dey, C.S. Effect of Chromium and Zinc on Insulin Signaling in Skeletal Muscle Cells. Biol. Trace Elem. Res. 2004, 101, 19-36. [CrossRef]

137. Foster, M.; Samman, S. Zinc and Regulation of Inflammatory Cytokines: Implications for Cardiometabolic Disease. Nutrients 2012, 4, 676-694. [CrossRef] [PubMed]

138. König, D.; Weinstock, C.; Keul, J.; Northoff, H.; Berg, A. Zinc, iron, and magnesium status in athletes-influence on the regulation of exercise-induced stress and immune function. Exerc. Immunol. Rev. 1998, 4, 2-21. [PubMed]

139. Freeland-Graves, J.H.; Ebangit, M.L.; Bodzy, P.W. Zinc and copper content of foods used in vegetarian diets. J. Am. Diet. Assoc. $1980,77,648-654$.

140. Foster, M.; Chu, A.; Petocz, P.; Samman, S. Effect of vegetarian diets on zinc status: A systematic review and meta-analysis of studies in humans. J. Sci. Food Agric. 2013, 93, 2362-2371. [CrossRef]

141. Hunt, J.R.; Matthys, L.A.; Johnson, L.K. Zinc absorption, mineral balance, and blood lipids in women consuming controlled lactoovovegetarian and omnivorous diets for 8 wk. Am. J. Clin. Nutr 1998, 67, 421-430. [CrossRef]

142. Maret, W.; Sandstead, H.H. Zinc requirements and the risks and benefits of zinc supplementation. J. Trace Elem. Med. Biol. 2006, 20,3-18. [CrossRef]

143. 143. Trumbo, P.; Yates, A.A.; Schlicker, S.; Poos, M. Dietary reference intakes: Vitamin A, Vitamin K, arsenic, boron, chromium, copper, iodine, iron, manganese, molybdenum, nickel, silicon, vanadium, and zinc. J. Am. Diet. Assoc. 2001, 101, $294-301$. [CrossRef]

144. Om, A.-S.; Chung, K.-W. Dietary Zinc Deficiency Alters $5 \alpha$-Reduction and Aromatization of Testosterone and Androgen and Estrogen Receptors in Rat Liver. J. Nutr. 1996, 126, 842-848. [CrossRef] [PubMed]

145. Swerdloff, R.S.; Dudley, R.E.; Page, S.T.; Wang, C.; Salameh, W. Dihydrotestosterone: Biochemistry, Physiology, and Clinical Implications of Elevated Blood Levels. Endocr. Rev. 2017, 38, 220-254. [CrossRef] [PubMed]

146. Grino, P.B.; Griffin, J.E.; Wilson, J.D. Testosterone at High Concentrations Interacts with the Human Androgen Receptor Similarly to Dihydrotestosterone*. Endocrinol. 1990, 126, 1165-1172. [CrossRef] [PubMed]

147. Gao, W.; Bohl, C.E.; Dalton, J.T. Chemistry and Structural Biology of Androgen Receptor. Chem. Rev. 2005, 105, 3352-3370. [CrossRef] [PubMed]

148. Wilson, E.M.; French, F.S. Binding properties of androgen receptors. Evidence for identical receptors in rat testis, epididymis, and prostate. J. Biol. Chem. 1976, 251, 5620-5629. [CrossRef] 
149. Marchetti, P.M.; Barth, J.H. Clinical biochemistry of dihydrotestosterone. Ann. Clin. Biochem. 2013, 50, 95-107. [CrossRef]

150. Bernstein, K.E.; Khan, Z.; Giani, J.F.; Cao, D.-Y.; Bernstein, E.A.; Shen, X.Z. Angiotensin-converting enzyme in innate and adaptive immunity. Nat. Rev. Nephrol. 2018, 14, 325-336. [CrossRef]

151. Towler, P.; Staker, B.; Prasad, S.G.; Menon, S.; Tang, J.; Parsons, T.; Ryan, D.; Fisher, M.; Williams, D.; Dales, N.A.; et al. ACE2 X-Ray Structures Reveal a Large Hinge-bending Motion Important for Inhibitor Binding and Catalysis. J. Biol. Chem. 2004, 279, 17996-18007. [CrossRef]

152. Kwok, T.; Ohlsson, C.; Vandenput, L.; Tang, N.; Zhang, Y.; Tomlinson, B.; Leung, P. ACE inhibitor use was associated with lower serum dehydroepiandrosterone concentrations in older men. Clin. Chim. Acta 2010, 411, 1122-1125. [CrossRef] [PubMed]

153. Prasad, A.S.; Mantzoros, C.S.; Beck, F.W.; Hess, J.W.; Brewer, G.J. Zinc status and serum testosterone levels of healthy adults. Nutrition 1996, 12, 344-348. [CrossRef]

154. Jalali, G.R.; Roozbeh, J.; Mohammadzadeh, A.; Sharifian, M.; Sagheb, M.M.; Jahromi, A.H.; Shabani, S.; Ghaffarpasand, F.; Afshariani, R. Impact of oral zinc therapy on the level of sex hormones in male patients on hemodialysis. Ren. Fail. 2010, 32, 417-419. [CrossRef] [PubMed]

155. Santos, H.O.; Teixeira, F. Use of medicinal doses of zinc as a safe and efficient coadjutant in the treatment of male hypogonadism. Aging Male 2020, 23, 669-678. [CrossRef]

156. McClung, J.P. Iron, Zinc, and Physical Performance. Biol. Trace Elem. Res. 2018, 188, 135-139. [CrossRef]

157. Chu, A.; Holdaway, C.; Varma, T.; Petocz, P.; Samman, S. Lower Serum Zinc Concentration Despite Higher Dietary Zinc Intake in Athletes: A Systematic Review and Meta-analysis. Sports Med. 2017, 48, 327-336. [CrossRef]

158. Koehler, K.; Parr, M.K.; Geyer, H.; Mester, J.; Schänzer, W. Serum testosterone and urinary excretion of steroid hormone metabolites after administration of a high-dose zinc supplement. Eur. J. Clin. Nutr. 2007, 63, 65-70. [CrossRef]

159. Kilic, M. Effect of fatiguing bicycle exercise on thyroid hormone and testosterone levels in sedentary males supplemented with oral zinc. Neuro Endocrinol. Lett. 2007, 28, 681-685.

160. Shafiei Neek, L.; Gaeini, A.A.; Choobineh, S. Effect of zinc and selenium supplementation on serum testosterone and plasma lactate in cyclist after an exhaustive exercise bout. Biol. Trace Elem. Res. 2011, 144, 454-462. [CrossRef]

161. Volpe, S.L. Magnesium in Disease Prevention and Overall Health. Adv. Nutr. 2013, 4, 378S-383S. [CrossRef]

162. Volpe, S.L. Magnesium and the Athlete. Curr. Sports Med. Rep. 2015, 14, 279-283. [CrossRef]

163. Institute of Medicine (US) Standing Committee on the Scientific Evaluation of Dietary Reference Intakes. Dietary Reference Intakes for Calcium, Phosphorus, Magnesium, Vitamin D, and Fluoride. National Academies Press: Washington, DC, USA, 1997.

164. de Sousa, E.F.; Da Costa, T.H.; Nogueira, J.A.; Vivaldi, L.J. Assessment of nutrient and water intake among adolescents from sports federations in the Federal District, Brazil. Br. J. Nutr. 2008, 99, 1275-1283. [CrossRef] [PubMed]

165. Juzwiak, C.R.; Amancio, O.M.S.; Vitalle, M.S.S.; Pinheiro, M.M.; Szejnfeld, V.L. Body composition and nutritional profile of male adolescent tennis players. J. Sports Sci. 2008, 26, 1209-1217. [CrossRef] [PubMed]

166. Heaney, S.; O'Connor, H.; Gifford, J.; Naughton, G. Comparison of strategies for assessing nutritional adequacy in elite female athletes' dietary intake. Int. J. Sport Nutr. Exerc. Metab. 2010, 20, 245-256. [CrossRef]

167. Silva, M.R.; Paiva, T. Low energy availability and low body fat of female gymnasts before an international competition. Eur. J. Sport Sci. 2015, 15, 591-599. [CrossRef]

168. Maggio, M.; De Vita, F.; Lauretani, F.; Nouvenne, A.; Meschi, T.; Ticinesi, A.; Dominguez, L.J.; Barbagallo, M.; Dall’Aglio, E.; Ceda, G.P. The Interplay between Magnesium and Testosterone in Modulating Physical Function in Men. Int. J. Endocrinol. 2014, 2014, 1-9. [CrossRef]

169. Maggio, M.; Ceda, G.P.; Lauretani, F.; Cattabiani, C.; Avantaggiato, E.; Morganti, S.; Ablondi, F.; Bandinelli, S.; Dominguez, L.J.; Barbagallo, M.; et al. Magnesium and anabolic hormones in older men. Int. J. Androl. 2011, 34, e594-e600. [CrossRef] [PubMed]

170. Rotter, I.; Kosik-Bogacka, D.; Dołegowska, B.; Safranow, K.; Karakiewicz, B.; Laszczyńska, M. Relationship between serum magnesium concentration and metabolic and hormonal disorders in middle-aged and older men. Magnes. Res. 2015, 28 , 99-107. [CrossRef] [PubMed]

171. Cinar, V.; Polat, Y.; Baltaci, A.K.; Mogulkoc, R. Effects of magnesium supplementation on testosterone levels of athletes and sedentary subjects at rest and after exhaustion. Biol. Trace Elem. Res. 2011, 140, 18-23. [CrossRef] [PubMed]

172. Barbagallo, M.; Dominguez, L.J. Magnesium and Aging. Curr. Pharm. Des. 2010, 16, 832-839. [CrossRef]

173. Dickens, B.; Weglicki, W.; Li, Y.-S.; Mak, I. Magnesium deficiency in vitro enhances free radical-induced intracellular oxidation and cytotoxicity in endothelial cells. FEBS Lett. 1992, 311, 187-191. [CrossRef]

174. Freedman, A.M.; Mak, I.T.; Stafford, R.E.; Dickens, B.F.; Cassidy, M.M.; Muesing, R.A.; Weglicki, W.B. Erythrocytes from magnesium-deficient hamsters display an enhanced susceptibility to oxidative stress. Am. J. Physiol. Physiol. 1992, 262, C1371-C1375. [CrossRef] [PubMed]

175. Demirbag, R.; Yilmaz, R.; Erel, O. The association of total antioxidant capacity with sex hormones. Scand. Cardiovasc. J. 2005, 39, 172-176. [CrossRef] [PubMed]

176. Blache, D.; Devaux, S.; Joubert, O.; Loreau, N.; Schneider, M.; Durand, P.; Prost, M.; Gaume, V.; Adrian, M.; Laurant, P.; et al. Long-term moderate magnesium-deficient diet shows relationships between blood pressure, inflammation and oxidant stress defense in aging rats. Free. Radic. Biol. Med. 2006, 41, 277-284. [CrossRef]

177. Hans, C.P.; Chaudhary, D.P.; Bansal, D.D. Effect of magnesium supplementation on oxidative stress in alloxanic diabetic rats. Magnes. Res. 2003, 16, 13-19. [PubMed] 
178. Yang, Y.; Wu, Z.; Chen, Y.; Qiao, J.; Gao, M.; Yuan, J.; Nie, W.; Guo, Y. Magnesium Deficiency Enhances Hydrogen Peroxide Production and Oxidative Damage in Chick Embryo Hepatocyte In Vitro. BioMetals 2006, 19, 71-81. [CrossRef]

179. Afanas'Ev, I.B.; Suslova, T.B.; Cheremisina, Z.P.; Abramova, N.E.; Korkina, L.G. Study of antioxidant properties of metal aspartates. Analyst 1995, 120, 859-862. [CrossRef]

180. Nielsen, F.H.; Johnson, L.K.; Zeng, H. Magnesium supplementation improves indicators of low magnesium status and inflammatory stress in adults older than 51 years with poor quality sleep. Magnes. Res. 2011, 23, 158-168. [CrossRef]

181. Weglicki, W.B.; Dickens, B.F.; Wagner, T.L.; Chmielinska, J.J.; Phillips, T.M. Immunoregulation by neuropeptides in magnesium deficiency: Ex vivo effect of enhanced substance P production on circulating T lymphocytes from magnesium-deficient mice. Magnes. Res. 1996, 9, 3-11.

182. Nielsen, F.H.; Lukaski, H.C. Update on the relationship between magnesium and exercise. Magnes. Res. 2006, 19, 180-189.

183. I Spratt, D.; Orav, J.; Moloney, J.; Bigos, T.; Cox, P. Reproductive axis suppression in acute illness is related to disease severity. J. Clin. Endocrinol. Metab. 1993, 76, 1548-1554. [CrossRef]

184. Hong, C.Y.; Park, J.H.; Ahn, R.S.; Im, S.Y.; Choi, H.-S.; Soh, J.; Mellon, S.H.; Lee, K. Molecular Mechanism of Suppression of Testicular Steroidogenesis by Proinflammatory Cytokine Tumor Necrosis Factor Alpha. Mol. Cell. Biol. 2004, 24, 2593-2604. [CrossRef] [PubMed]

185. Lawrence, T. The nuclear factor NF-kappaB pathway in inflammation. Cold. Spring Harb. Perspect. Biol. 2009,1, a001651. [CrossRef] [PubMed]

186. Rochelson, B.; Dowling, O.; Schwartz, N.; Metz, C.N. Magnesium sulfate suppresses inflammatory responses by human umbilical vein endothelial cells (HuVECs) through the NFkappaB pathway. J. Reprod. Immunol. 2007, 73, 101-107. [CrossRef] [PubMed]

187. Steward, C.J.; Zhou, Y.; Keane, G.; Cook, M.D.; Liu, Y.; Cullen, T. One week of magnesium supplementation lowers IL-6, muscle soreness and increases post-exercise blood glucose in response to downhill running. Graefe's Arch. Clin. Exp. Ophthalmol. 2019, 119, 2617-2627. [CrossRef] [PubMed]

188. Excoffon, L.; Guillaume, Y.; Woronoff-Lemsi, M.; André, C. Magnesium effect on testosterone-SHBG association studied by a novel molecular chromatography approach. J. Pharm. Biomed. Anal. 2009, 49, 175-180. [CrossRef]

189. Emadi-Konjin, P.; Bain, J.; Bromberg, I.L. Evaluation of an algorithm for calculation of serum "bioavailable" testosterone (BAT). Clin. Biochem. 2003, 36, 591-596. [CrossRef] 